\title{
DO PUBLIC TUITION SUBSIDIES PROMOTE COLLEGE ENROLLMENT? EVIDENCE FROM COMMUNITY COLLEGE TAXING DISTRICTS IN TEXAS
}

\author{
by \\ Paco Martorell \\ RAND Corporation
}

\author{
Brian McCall \\ University of Michigan
}

Is aac McFarlin

University of Michigan

CES 14-32

Septembber, 2014

The research program of the Center for Economic Studies (CES) produces a wide range of economic analyses to improve the statistical programs of the U.S. Census Bureau. Many of these analyses take the form of CES research papers. The papers have not undergone the review accorded Census Bureau publications and no endorsement should be inferred. Any opinions and conclusions expressed herein are those of the author(s) and do not necessarily represent the views of the U.S. Census Bureau. All results have been reviewed to ensure that no confidential information is disclosed. Republication in whole or part must be cleared with the authors.

To obtain information about the series, see www.census.gov/ces or contact Fariha Kamal, Editor, Discussion Papers, U.S. Census Bureau, Center for Economic Studies 2K132B, 4600 Silver Hill Road, Washington, DC 20233, CES.Papers.List@census.gov. 


\begin{abstract}
This paper estimates the effect of tuition rates on college enrollment using data for Texas from the 1990 and 2000 Censuses and the 2004 - 2010 American Community Surveys and geographical data on Community College Taxing Districts. The effect of tuition on enrollment is identified by the facts that tuition rates for those living within a taxing district are lower than those living outside the taxing district and in Texas not all geographic locations are in a taxing district. While the estimated effect of tuition on enrollment depends on the sample used, it is negative and mostly statistically significant in the samples of iadults 18 and older and negative and sometimes statistically significant in the samples of traditional age students 18 to 24 . The estimated effect of tuition on enrollment, however, is found to vary considerably by poverty level status with an increase in tuition rates having a statistically significant negative effect on college enrollment for those with household incomes that are at least $200 \%$ of the poverty level both for traditional aged students 18 to 24 years old and all adults 18 and older.
\end{abstract}




\section{Introduction}

Most developed countries now realize that in order to effectively compete in the global economy it is necessary to have a highly skilled workforce. Because of this national leaders, including those in the Unites States, have called for substantial increases in the fraction of their country's workforce with postsecondary degrees.

In the United States, a sizeable fraction of postsecondary education costs are subsidized by state governments. In 2012-2013 state appropriations were $\$ 72$ billion. Federal aid from Pell grants, on the other hand, was about $\$ 32$ billion while aid from federal education tax benefits was approximately $\$ 20$ billion (College Board, 2013a). Over the last twenty years tuition at public two-year colleges has risen over $60 \%$ in constant dollars while tuition at public four-year colleges has increased by over 115\% (College Board, 2013b).

Inflation adjusted state appropriations have been declining over time in the United States, especially recently. For example, from 2007-2008 to 2012-2013 total state appropriations declined by 19\% (College Board, 2013a). At the same time enrollment at public institutions has been increasing. This has lead to large increases in listed tuition rates (College Board, 2013b). While some of these tuition increases have been partially offset for low income students by increases in grant aid, many students have had to increase the amount they pay out of pocket and/or have had to increase their amount of student debt.

For some individuals the higher price tag of postsecondary education may discourage them from attending. The literature on the effect of tuition on the probability of college enrollment has produced a range of results varying from a four percentage point decrease in enrollment for a $\$ 1000$ dollar increase in tuition based on early research (Leslie and Brinkman, 1987) up to a 16 percentage point decrease (Kane, 1995). While the early studies identified the effect using variation over time (Leslie and Brinkman, 1987) at a single 
institution or state, more recent studies have used variation within a state over time in average four-year (Kane, 1994 and Cameron and Heckman, 1999) or two-year (Kane, 1995) tuition rates. On potential source of bias that is not accounted for in these studies, even among those that control for state and year fixed effects, is that changes in average tuition rates may be related to changes in unobserved state-level variables (e.g., unmeasured changes in labor market conditions) that influence the probability of college enrollment (Card and Lemieux, 2000).

This paper uses a novel source of variation to identify the effect of tuition on college attendance. In many states, the tuition an individual pays for attending a community college depends on their location of residence. If you live within a community college taxing district (CCTD) your tuition rate for attending a community college in that district is lower than for someone whose residence is outside that particular CCTD. If all residences in a state were within a CCTD, then individuals located in CCTD's with low tuition rates might be more likely to attend a community college within their CCTD compared to individuals located in CCTD's with high tuition rates. However, this cross-CCTD variation in-district tuition rates would potentially be confounded with, for example, unobserved attributes of the community colleges across CCTDs. ${ }^{1}$ However, in Texas not all residences are located in a CCTD. Thus, individuals not living inside any CCTD will have to pay a higher out-ofdistrict tuition rate even for the community college that is closest to their place of residence. In this paper we exploit this type of variation to estimate the effect of tuition rates on college attendance. In particular, we use twenty years of geocoded data on community college district boundaries merged to data from the 1990 and 2000 Census and $2004-2010$

\footnotetext{
1 This is similar to the problem of trying to estimate the effect of tuition on enrollment using cross-state variation in average tuition rates.
} 
American Community Surveys (ACS) to estimate the effect of tuition rates on college attendance. Based on our estimates from the main empirical model, a $\$ 1000$ increase in tuition is estimated to statistically significantly decrease college enrollment rates of 18-24 year olds by 5.4 percentage points for the 2000 Census sample. The point estimates for the 1990 Census and 2004 - 2010 ACS 18-24 year old samples, while negative, are small and imprecise. Estimates from the 1990 and 2000 Census samples of adults 18 and older imply that a $\$ 1000$ increase in tuition will statistically significantly decrease college enrollment rates 3.3 and 2.1 percentage points, respectively. The estimated effect of the tuition rate for the 2004 - 2010 ACS of individuals 18 and older while negative is not statistically significant.

There is however, substantial heterogeneity in the estimated effect by the poverty level of the household of the individual. In fact the estimated effect is either positive or if negative, not statistically significant for individuals living in households below $200 \%$ of the poverty level. This may be due to the fact that tuition rate increases for these low income individuals may be offset, at least partially, by increases in the amount of Pell grants that they qualify for. ${ }^{2}$ However, for individuals in families whose income places them at $200 \%$ of the poverty level or above, the estimated effects are always negative, and mostly statistically significant, and imply that a $\$ 1000$ increase in tuition will decrease enrollment by from between 2.4 and 11.5 percentage points depending on poverty level group and sample for individuals between 18 and 24 years old and from between 0.7 and 5.6 percentage points for individuals ages 18 and older.

\footnotetext{
${ }^{2}$ For example, in 2014 a family of 4 with 1 dependent child in college would qualify for the up to the maximum Pell amount if family income was 100\% the poverty level, up to about $\$ 3500$ if family income was $200 \%$ the poverty level, and not qualify for a Pell if the family income was $300 \%$ of poverty level or higher.
} 
The remainder of this paper is organized as follows. After discussing the data in section 2 , section 3 presents the estimation methodology. Since we assign tuition rates to individuals on the basis of the closest CCTD (which would be the in-district tuition rate for those living within the CCTD and the out-of-district tuition rate for those living outside the CCTD), the effect of tuition on college enrollment is identified at a single point in time in models that include CCTD fixed effects. Section 4 presents the estimations results including some tests for heterogeneous effects by an individual's race, gender, and the poverty status of their household. This section also presents the results of some robustness checks. The final section presents a summary, discusses some of the limitations of the paper and offers some suggestions for future research.

\section{Data}

This paper employs data from the 1990 and 2000 U.S. Decennial Censuses 1\% and 5\% sample and data from the $2004-2010$ American Community Surveys (ACS) for the state of Texas along with GIS data mapping the CCTD boundaries for Texas over the 19912010 period and data on the census block location of community colleges over the same period of time. Using the confidential census block identifiers in the Census and ACS data along with the GIS data, we calculated the distance to every community college main campus in Texas and the (closest) distance to every community college taxing district for each household in the three sets of data. ${ }^{3}$ Most public community colleges in the U.S. are organized around such special districts (Cohen and Brawer, 2003). Texas has 67 public community colleges, which occupy 50 community college taxing districts. Figure 1 presents

\footnotetext{
${ }^{3}$ For individuals living within a particular CCTD the distance to the boundary of that CCTD is denoted by a negative number.
} 
the CCTD boundaries in Texas for 2010. As can be seen from the figure, a substantial fraction of the geographical area of Texas is not located in a CCTD. Virtually every metropolitan area in Texas, however, is located within a CTTD.

Finally, using this geographic location information and community college tuition data that were gathered from several sources, we determined for each individual the tuition rate (per semester) they would face if they attended full-time (15 credits) a community college in the CCTD in which they live (in 2010 constant dollars). For individuals who do not live in any CCTD, the tuition rate assigned to them is the tuition they would have to pay for full-time attendance at the community college in the CCTD that is closest to them. Individuals who do not live in a CCTD pay a higher tuition rate than those who do. Figure 2 presents the tuition rate for adults who live in a particular CCTD versus the tuition rate for those living outside the particular CCTD for all CCTDs in Texas in 2010. The difference between living outside a CCTD and living inside a CCTD are presented in Figure 3. As can be seen in this figure there is substantial variation in the tuition differences across the CCTDs ranging from $\$ 0$ for Weatherford BMD and Frank Phillips BMD to $\$ 1565$ for Austin.

Since we are interested in the effect of community college tuition rates on college attendance, our samples were restricted to those individuals 18 and older that have either at least high school diploma or a GED, but have no post secondary degree such as an AA, BA, MA or PhD. This results in samples sizes of about $710,400,1,059,400$, and 440,900 for the 1990 Census, 2000 Census, and 2004-2010 ACS data, respectively.

The Census and ACS data have information about whether an individual has attended a college in the previous three months. Additionally there is information about whether the college they attend is public or private. Unfortunately there is no information 
contained in the Census or ACS data about whether the individual attended a community college or a four-year university. Since the tuition differences between those living inside a CTTD and those living outside a CCTD refer to public community colleges we also estimated models focusing on enrollment in a public post-secondary institution. ${ }^{4}$

In 1990 Census sample, around 51\% of individuals 18 years and older who graduated high school but had no post-secondary degree lived inside a community college taxing district. For the 2000 sample this percentage had increased to $56 \%$ while the percentage further increased to $63 \%$ for the 2004-2010 ASC sample. Table 1 presents summary statistics broken down broken down by whether or the individual lives in a CCTD. As can be seen from the table, while there are no substantial differences between those living in CCTDs and those living outside CCTDs in the fraction of 18-24 year olds attending any college, among individuals 18 and older the fraction attending any college is generally higher for those living inside as opposed to outside the CCTD. For example, in 1990 the fraction of individuals 18 and older attending college was 13.6\% for those residing in a CCTD as opposed to $12.5 \%$ for those not residing in a CCTD. For 2000 the difference was about 1.9 percentage points $(9.9 \%$ versus $8.0 \%)$ and for the $2004-2010$ period the difference was 2.2 percentage points $(11.9 \%$ versus $9.7 \%)$.

The average age of adults residing in CCTD's is younger than those not residing in any CCTD (40.6 versus 41.4 in the 1990 Census, 42.3 versus 44.5 in the 2000 Census and 40.13 versus 42.1 in the $2004-2010$ ACS). There has been a dramatic change in the ethnic makeup in Texas over the last few decades and this is reflected in the samples. In the 1990

\footnotetext{
${ }^{4}$ Data from the 2009 Integrated Postsecondary Education Data System show that for Texas in the fall of 2008, 54,881 students enrolled full-time in public two-year colleges while 10, 705 enrolled full-time in private for-profit institutions. The corresponding numbers for parttime enrollment are 47,108 and 826, respectively.
} 
Census sample the percentage of whites equaled 82.8 . This decreases to $64.5 \%$ in the 2000 Census sample and further to 57.3\% in 2004-2010 ACS sample. While the fraction of Blacks has remained relatively stable over this time period, the fraction of Hispanics has increased dramatically, from $5.45 \%$ in the 1990 Census sample to $21.9 \%$ in the 2000 Census sample and $27.9 \%$ in the 2004-2010 ACS sample. Among those living in CCTDs, the fraction of whites is lower than among those not living in a CCTD and this difference has been increasing over time. In the 1990 Census sample the fraction of whites living in a CCTD was 7.6 percentage points lower than those not living in a CCTD. This difference increased to 17.0 percentage points in the 2000 Census sample and to 19.0 percentage points in the 2004-2010 ACS sample. While the fraction of individuals in households whose income is at least 500\% the poverty level was larger for those living in CCTDs in the 1990 Census sample (23.1 versus 19.7) in the 2004-2010 ACS sample the fraction of individuals in households whose income is at least 500\% the poverty level was lower for those living in CCTDs versus those not living inside a CCTD (24.2 versus 26.6). For additional results see Table 1.

\section{Methodology}

To examine the effect of tuition rates on the probability of attending college we estimated a series of linear probability models. The main source of tuition variation that we exploit is the variation arising from the fact that individuals living inside community college taxing districts face lower tuition rates than those living outside a community college taxing district. With the 1990 and 2000 Census data we estimate the model

$$
y_{i}=\alpha T_{i j}+\beta^{\prime} \mathbf{x}_{i}+\delta_{j}+\varepsilon_{i}
$$


where $T_{i j}$ is the tuition faced by individual $i$ whose closest taxing district is $j, \boldsymbol{x}_{i}$ is a vector of characteristics of individual $i, \delta_{j}$ is a fixed effect for the $j^{\text {th }}$ CCTD and $\epsilon_{i}$ is the error term. Since the ACS data pools data from 2004 to 2010 we estimate

$$
y_{i t}=\alpha T_{i j t}+\beta^{\prime} \mathbf{x}_{i t}+\delta_{j}+\mu_{t}+\varepsilon_{i t}
$$

where $T_{i j t}$ is the tuition faced by individual $i$ whose closest taxing district is $j$ in year $t, \boldsymbol{x}_{i t}$ is a vector of characteristics of individual $i$ in year $t, \delta_{j}$ is a fixed effect for the $j^{\text {th }}$ CCTD, $\mu_{t}$ is a year effect, and $\epsilon_{i t}$ is the error term. We can identify the effect of $T_{i j}$ on enrollment in the Census data, even though there is no time-variation in tuition rates, because individuals who live inside the $j^{\text {th }}$ CTTD face a lower tuition rate than those whose closest CCTD is $j$ but live outside any CCTD.

In addition to the tuition rate faced by an individual, we also controlled for several other factors that may influence whether an individual attends college. In particular, we controlled for an individual's age, race, gender, and the interaction of race with gender, whether the individual has a disability, the individual's place of birth (Texas, outside Texas in United States, outside United States), whether the household migrated within the last five years for the Census data and within the last year for the ACS data (migrated, migrated within Texas, migrated across counties within Texas), household poverty status $(<100 \%$ poverty level, $100 \%-199 \%$ of poverty level, $200 \%-299 \%$ of poverty level, $300 \%-399 \%$ of poverty level, $400 \%-499 \%$ of poverty level, $500 \%+$ poverty level) and weeks worked in the previous year. We also include as a control in our estimations the distance from the census block in which an individual resides to the closest community college since individuals who live further from a college are, all else equal, less likely attend college but are also more likely to live outside a CCTD and, hence, pay a higher tuition rate. 
We estimate models first by restricting the sample to individuals $18-24$ years old. These are the ages that individuals traditionally attend college. In other estimations, we include all adults 18 and older. In order to investigate whether the effect of tuition rates on the probability of college attendance varies by different subgroups we also estimated models that included as control variables, interactions of the tuition variable with, race, gender, and poverty status. In all our estimates we cluster the standard errors at the Census tract level.

These regression models will yield unbiased estimates of the effect of tuition rates on college attendance only if there are no uncontrolled differences related to both the probability of college attendance and tuition rates. To test the sensitivity of the estimates, an alternative model is estimated that identifies the effect of tuition rates on college attendance by using variation across CCTDs in the tuition differences between those living within the CCTD and those living outside a CCTD. Define the subsidy amount that an individual receives as the difference between the out-of-district tuition rate and the actual tuition rate that an individual pays. The subsidy of individuals living outside a CCTD is then equal to 0 while the tuition subsidy for those living within a CCTD is equal to the difference between the out-of-district and in-district tuition rate. The subsidy effect is estimated by comparing differences in the probability of attending college between those living inside a CCTD with a subsidy above the median subsidy level to those living inside a CCTD with a subsidy below median subsidy level. The implicit assumption is that for both low subsidy and high subsidy CCTDs those living inside the CCTD may differ from those living outside the CCTD for unobserved differences that may be correlated with college attendance, but only those living in a high tuition subsidy CCTD are directly affected by the tuition subsidy. ${ }^{5}$ Let $\mathrm{HS}_{i j}$ be a

\footnotetext{
5 Alternatively, all else equal, the difference between those living within a low subsidy CCTD and those living outside the CCTD could equal $\eta+\alpha_{1}$ and the difference between those
} 
dummy variable that equals one if an individual $i$ resides in a high tuition subsidy taxing district $j$ and equals zero, otherwise. Also let $\mathrm{I}_{i j}$ be a dummy variable that equals 1 if an individual $i$ lives in taxing district $j$ and equals 0 otherwise. The model is then for the Census data

$$
y_{i}=\alpha H S_{i j}+\boldsymbol{\beta}^{\prime} \mathbf{x}_{i}+\rho I_{i j}+\delta_{j}+\varepsilon_{i}
$$

where the parameter $\alpha$ measures the effect of the tuition subsidy on the probability of college enrollment. For the ACS data we have

$$
y_{i t}=\alpha H S_{i j t}+\beta^{\prime} \mathbf{x}_{i t}+\rho I_{i j t}+\delta_{j}+\mu_{t}+\varepsilon_{i t} .
$$

\section{Empirical Results}

Table 2 presents the main estimation results for the 1990 Census, 2000 Census, and 2004-2010 ACS samples. Columns (1) and (2) report the estimates from the models in eqautions (1) and (2) when the sample is restricted to traditional college students aged 18-24 years old while columns (3) and (4) report the estimates for the sample of adults aged 18 and older. The estimates presented in panel A have college attendance as the dependent variable while the estimates shown in panel B have public college attendance as the dependent variable. Columns (1) and (3) report estimates when the distance to the closest community college is excluded as a control variable while columns (2) and (4) report estimates when the distance to the closest community college is included as a control variable.

living within a high subsidy CCTD and those living outside the CCTD could equal $\eta+\alpha_{1}+$ $\alpha_{\mathrm{h}}$ where $\eta$ are unobserved differences in college attendance probabilities unrelated to tuition. The parameters $\eta$ and $\alpha_{1}$, however, are not separately identified. 
As can be seen from column (1) of panel A, when the distance to the closest community college is excluded from the estimations the estimated effect of an increase in community college tuition on college attendance for traditional college students is negative and statistically significant for all three samples with point estimates implying that a $\$ 1000$ increase in (semester) tuition rates would lower the college enrollment rates of traditional age students from between 4.0 and 12.2 percentage points.

Including distance to the nearest community college as a control variable, however, leads to a substantial reduction in the estimated magnitude of the effect of tuition on the probability of college enrollment of traditional age students. As can be seen from column (2) of panel A, only the estimated effect for the 2000 Census sample remains statistically significant and implies that a $\$ 1000$ increase in tuition would decrease enrollment by 5.4 percentage points.

Columns (3) of panel A report the results for the full sample of adults when distance to the closest college is excluded from the regressions. The estimated effect of the tuition rate is negative and statistically significant for all samples. More specifically, the estimated effect of a $\$ 1000$ dollar increase in the tuition rate on enrollment ranges from a decrease in enrollment of 7.3 percentage points for the 1990 Census sample to a decrease in enrollment of 1.4 percentage points for the 2004-2010 ACS sample. When distance to the closest college is included in the estimations, the estimated effects are smaller in magnitude but remain statistically significant for the 1990 and 2000 Census samples. The estimated effect of a $\$ 1000$ tuition increase is a decrease in enrollment of 3.3\% for the 1990 Census sample and $2.1 \%$ for the 2000 Census sample. 
The results when focusing on enrollment in public colleges reported in Panel B are similar to those in Panel A albeit smaller in absolute value. Again, controlling for distance to the closest community college reduces the magnitude of the estimated effect of tuition.

To check whether there is any evidence of heterogeneous effects of community college tuition rates on college enrollment, models were estimated that included interactions of the tuition variable with the race, gender, and poverty level variables. The estimated marginal effects of tuition on college enrollment by race, gender, and poverty level are presented in Tables $3-5$, respectively. For the sake of brevity we shall focus only the results of estimations that control for distance to the closest community college that are reported in columns (2) and (4) of the tables.

Looking first at the probability of attending any college, at conventional levels of statistical significance there is evidence of differential effects of tuition by race for the 1990 Census and 2000 Census samples but not for the 2004-2010 ACS sample. For the 1990 Census sample of individuals 18 and older, the estimated effect of tuition on college enrollment varies by race with whites being the only group where the tuition rate has a statistically significant negative effect on college enrollment. The point estimate for whites implies that a $\$ 1000$ dollar increase in tuition would decrease the probability of college enrollment by 4.1 percentage points.

For the 2000 Census sample of 18 to 24 year olds, there is statistical evidence of racial differences in the estimated effect of tuition rate on college enrollment with the estimate effects being negative and statistically significant for Native Americans, Asian Americans, and Hispanics. The point estimates imply that a $\$ 1000$ increase in tuition would decrease the probability of college enrollment by $14.6 \%, 7.6 \%$, and $9.2 \%$ for Native Americans, Asian Americans, and Hispanics, respectively. 
When enrollment in a public college is the outcome variable, the empirical results with respect to heterogeneous effects of tuition rates are similar to those when enrollment in any college is the dependent variable. One difference, however, is that for the 2000 Census sample of 18-24 year olds the estimated effect of the tuition rate, while still negative, is smaller in magnitude and no longer statistically significant for Asian Americans.

The only statistically significant evidence of gender differences in the estimated effect of tuition rates on the probability of college enrollment is for the 1990 Census sample of individuals 18 and older where the estimated decrease in enrollment for an increase in tuition is larger for males than females. For all colleges, the point estimate for males implies that a $\$ 1000$ increase in tuition would decrease the probability of enrollment by 3.9 percentage points while for females the estimated decrease is 2.5 percentage points. The later estimated effect, however, is not statistically significant. When focusing on public college enrollment the estimation results are similar except the point estimates are smaller in magnitude for both males and females, with the estimated effect for males now only statistically significant at the $10 \%$ level.

The results of testing for heterogeneous effects by poverty level are presented in columns (2) and (4) of Table 5 when a control for distance to the closest community college is included in the estimations. In general, there are statistically significant differences in the estimated effect of tuition rates on college enrollment for all samples, except for the 1990 sample of 18-24 year olds when the outcome variable is any college enrollment. The estimated effect of tuition is always positive and in many cases statistically significant for individuals in households at less than 100\% the poverty level. For individuals in households between 100 and 199\% of the poverty level, the estimated effect is both positive and negative depending on which sample is used and the outcome variable but is never 
statistically significant. For individual in households between $200 \%$ and $299 \%$ of the poverty level, the point estimates are always negative and mostly statistically significant while for individuals in households between 300\% and 399\% of the poverty level the point estimates are negative and always statistically significant for the 2000 Census and 2004-2010 ACS samples and negative and statistically significant for the 1990 Census sample of adults 18 and older. For the 1990 Census sample of 18 to 24 year olds the point estimates are not statistically significant. For individuals in households with income either between $400 \%$ and $499 \%$ of the poverty level or at $500 \%$ of the poverty level and above, the estimated effect is always negative and statistically significant.

Turning to the implied impacts for the 2000 Census sample of 18 to 24 year olds, the estimated effect of a $\$ 1000$ increase in tuition rate on the probability of college enrollment is a statistically significant 11.2 percentage points for those individuals in households at less than 100\% the poverty rate. For those individuals in households between $100 \%$ and $199 \%$ of the poverty level the estimated impact is negative but not statistically significant. For those between 200\% and 299\%, 300\% and 399\%, 400 and 499\%, and 500\% or above the poverty level the estimated effect is a decrease of $10.0,11.5,9.3$, and 10.5 percentage points, respectively, in the probability of enrollment in any college.

For the 2004-2010 ACS sample of 18-24 year olds, the estimated effect of a $\$ 1000$ increase in tuition on the probability of college enrollment for those less than $100 \%$ the poverty rate is a statistically significant increase of 8.3 percentage points. For those individuals in households between $100 \%$ and $199 \%$ of the poverty level, the estimated impact is negative but not statistically significant. For those individuals in households between $200 \%$ and $299 \%, 300 \%$ and $399 \%, 400$ and $499 \%$, and $500 \%$ or above the poverty 
level the estimated effect is a decline of $2.4,3.2,5.3$, and 3.3 percentage points, respectively, on the probability of enrollment in any college.

For the 1990 Census sample of 18 to 24 year olds the only statistically significant estimate is that associated with those at less then $100 \%$ of the poverty level and implies that a $\$ 1000$ increase in tuition would increase probability of enrollment in any college by 9.6 percentage points. The pattern of estimated effects when the outcome variable is enrollment in a public college is similar to those for enrollment in any college. See table 5 for details.

For individuals 18 and older, the estimated effect of a $\$ 1000$ increase in tuition rates on the probability of enrollment in any college for those at less than $100 \%$ of the poverty level is a 5.4, 8.6, and 3.5 percentage point increase for the 1990 Census, 2000 Census, and 2004-2010 ACS samples, respectively. For those between 100-199\% of the poverty level the estimated impact is not statistically significant for any sample. For the 1990 Census, 2000 Census, and 2004-2010 ACS samples, the estimated impact for individuals living in households with income between 200 and 299\% of the poverty level, is a statistically significant $4.8,3.2$, and 0.7 percentage point decrease in the probability of college enrollment, respectively, while the estimated impact for those living in households with income between 300 and $399 \%$ the poverty level is a statistically significant 4.6, 3.6, and 0.7 percentage point decrease in the probability of college enrollment, respectively. For individual living in households with income between 400 and $499 \%$ of the poverty level and for those living in households with income at 500\% the poverty level or above, the corresponding estimated impact of a $\$ 1000$ increase in tuition on the college enrollment are negative and statistically significant and equal 5.2, 3.7 and 1.0 and 5.6, 3.8, and 1.1 percent for the 1990 Census, 2000 Census, and 2004-2010 ACS samples, respectively. The pattern of 
estimated effects for adults 18 and older when the outcome variable is attending a public college is similar to those for enrollment in any college. See table 5 for details.

As mentioned above one potential limitation of the above analysis is that there may be unmeasured differences correlated with tuition rates between locations within a CCTD and locations outside CCTDs that are related to college enrollment. If this is the case then the estimated effect of community college tuition rates on college enrollment will be biased. To address this possibility we estimated the models described either by equations (3) for the 1990 and 2000 Census or (4) for the ASC both for those aged 18 to 24 and for adults 18 and older.

Model estimates are presented in Table 6 where columns (1) and (3) ((2) and (4)) present model estimates without (with) controls for distance to the closest community college and columns (1) and (2) ((3) and (4)) estimate models for adults aged 18 to 24 (18 and older). In panel A the dependent variable is enrollment in any college while in panel B the dependent variable is enrollment in a public college. For the sake of brevity we shall discuss only those estimation results that include distance to the closest community college as a control variable. Recall that we are focusing on tuition subsidies instead of tuition rates so the sign of the coefficient associated with the tuition subsidy variable should be the opposite of sign of that associated with the tuition rate variable

The estimated effect of residing in a CCTD with a high subsidy on the probability of enrollment in any college is positive and statistically significant for all samples of 18-24 year olds with estimates ranging from 0.029 for the 2004-2011 ACS sample to 0.069 for the 2000 Census sample. For the samples of individuals 18 and older, the estimates are also positive statistically significant but smaller in magnitude ranging from 0.010 for the 2004-2010 ACS sample to 0.021 for the 1990 Census sample. The estimated effect of a high tuition subsidy 
when the dependent variable is enrollment in a public college are all positive and statistically significant and the point estimates are at least as large as the estimates as when the dependent variable is enrollment in any college.

As shown in Table 7, there is statistically significant race differences in the estimated effect of a high tuition subsidy for the 2000 Census and 2004-2010 ACS samples, while as seen in columns (2) and (4) of Table 8, there are no statistically significant gender differences at conventional significance levels. Table 9 reports the results of tests for differences in the effect of a high tuition subsidy on the probability of enrollment by poverty level. Here we see that there are statistically significant differences the estimated effect of tuition subsidies on the probability of enrollment by poverty level for all samples except the 1990 Census sample of $18-24$ year olds and the 2000 Census sample of adults 18 and older when the outcome variable is enrollment in any college.

\section{Discussion and Conclusions}

This paper exploited the variation in tuition rates between those living in community college taxing districts and those living outside community college taxing districts in Texas to estimate the effect of tuition on college enrollment. Overall, there was evidence that increases in tuition rates statistically significantly reduced the probability of enrollment but further estimations revealed that the effect is mainly concentrated among individuals living in households whose income was equal to $300 \%$ or more of the poverty level. One limitation of this study is that the Census and ACS data do not distinguish between those who are attending community colleges and those attending four-year colleges and those attending. Lowering the community college tuition rate may cause some individuals to switch from attending a four-year college to attending a two-year college. While the extent of this 
cannot be determined from this data, in ongoing research of ours we are using administrative data from the UT-Dallas Education Research Center to estimate the magnitude of this “crowd-out” effect (also see McFarlin, 2007).

Another issue not addressed in this paper is the extent to which changes in tuition rates also affect college persistence and graduation rates and ultimately individual earnings levels. This is left to future research. We also did not exploit the fact that over time some community college taxing districts in Texas have been expanding. Thus, individuals living in certain geographic region may have outside any CCTD at one point in time but be within a CCTD at a latter point in time. This variation could form the basis of a difference in differences estimation. Again, we leave this to future research.

Finally, while we controlled for distance to the nearest community college, we did not include controls for distance to the closest four-year college. In future research, we plan to check the robustness of our findings to adding this measure as a control variable. We also are planning to investigate whether distance to the closest four-year college has a moderating effect on the impact of changes in community college tuition rates on college enrollment. Further, we are planning in the future to look at narrower distance bands around the community college and to look more explicitly at differences between traditional and non-traditional students. 


\section{References}

Cameron, Steven V. and Heckman, James J. (2001). "The Dynamics of Educational Attainment for Black, Hispanic, and White Males." Journal of Political Economy, 109(3): 455-499.

Card, David and Lemieux, Thomas (2000). "Dropout and Enrollment Trends in the Post-War Period: What Went Wrong in the 1970s?” National Bureau of Economic Research Working Paper No. 7658.

Cohen, Arthur M. and Brawer, Florence B. (2003). The American Community College $4^{\text {th }}$ Ed.) San Francisco, CA: Jossey-Bass.

College Board (2013a), Trends in College Pricing 2013. The College Board

College Board (2013b), Trends in Student Aid 2013. The College Board.

Kane, Thomas J. (1994). "College Entry by Blacks since 1970: The Role of College Costs, Family Background, and the Returns to Education," Journal of Political Economy, 102(5): 878-911.

Kane, Thomas J. (1995). "Rising Public Tuition and College Entry: How Well do Public Subsidies Promote Access to College?" National Bureau of Economic Research Working Paper No. 5164.

Leslie, Larry L. and Brinkman, Paul T. (1987). "Student Price Response in Higher Education: The Student Demand Studies.” Journal of Higher Education, 58(2): 181-204.

McFarlin, Isaac (2007). "Do Public Subsidies Promote College Access and Completion? Evidence from Community College Districts." Unpublished manuscript, UT-Dallas.

Waller, Lee (2003). "Disparities in Community College Finance: In-District Versus Out-of-District Funding," Community College Journal of Research and Practice. 27(5):409418. 
Figure 1

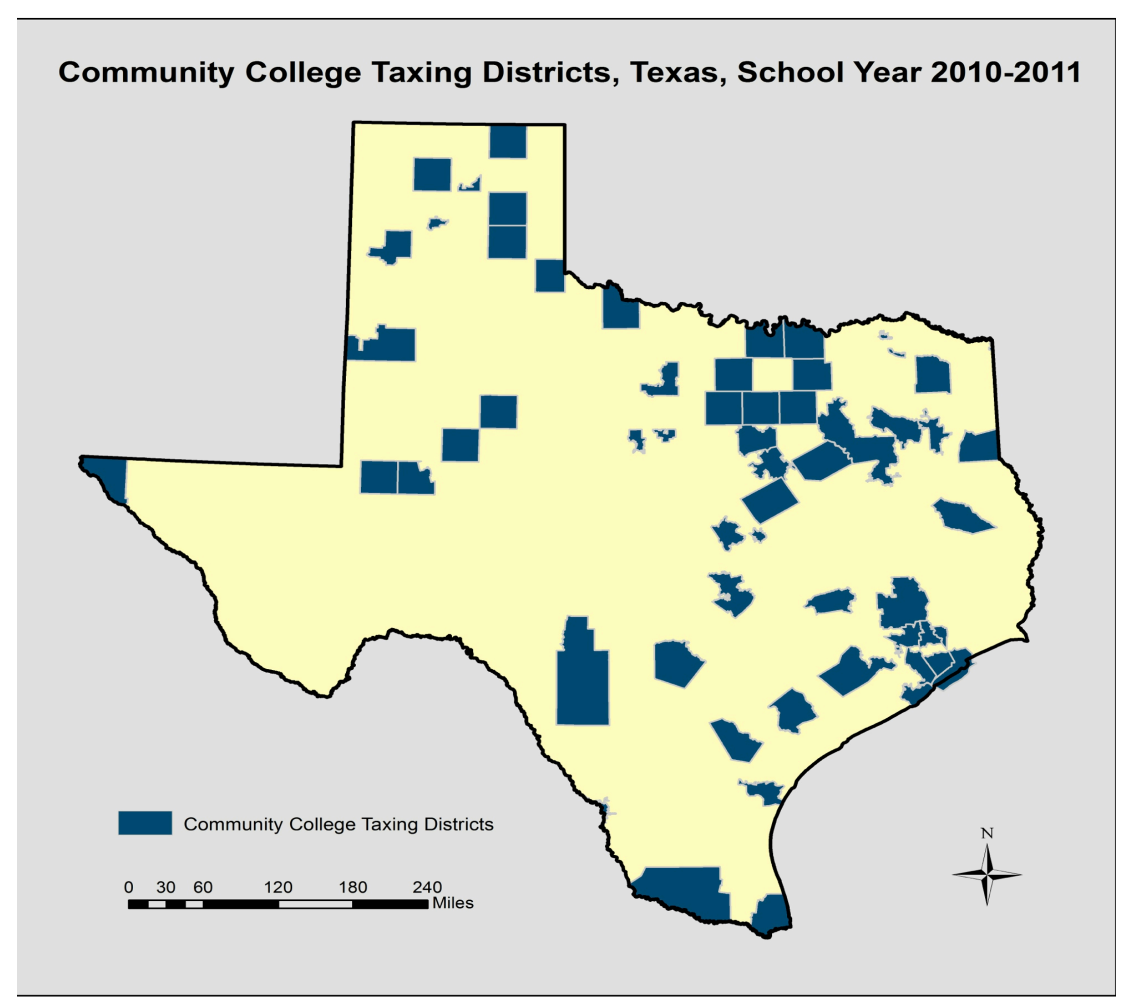


Figure 2

In-District and Out-of-District Annual Tuition, 2010

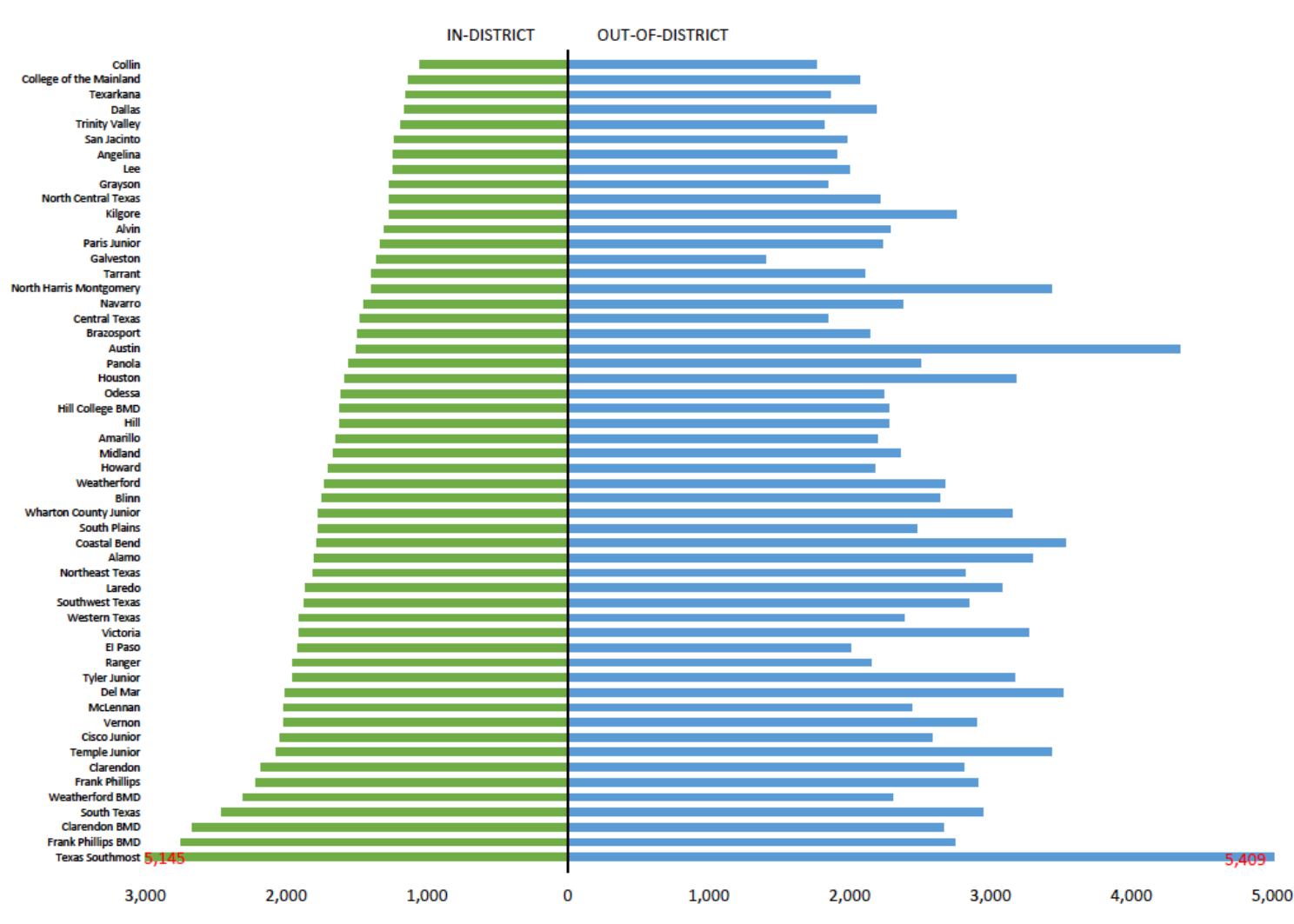


Figure 3

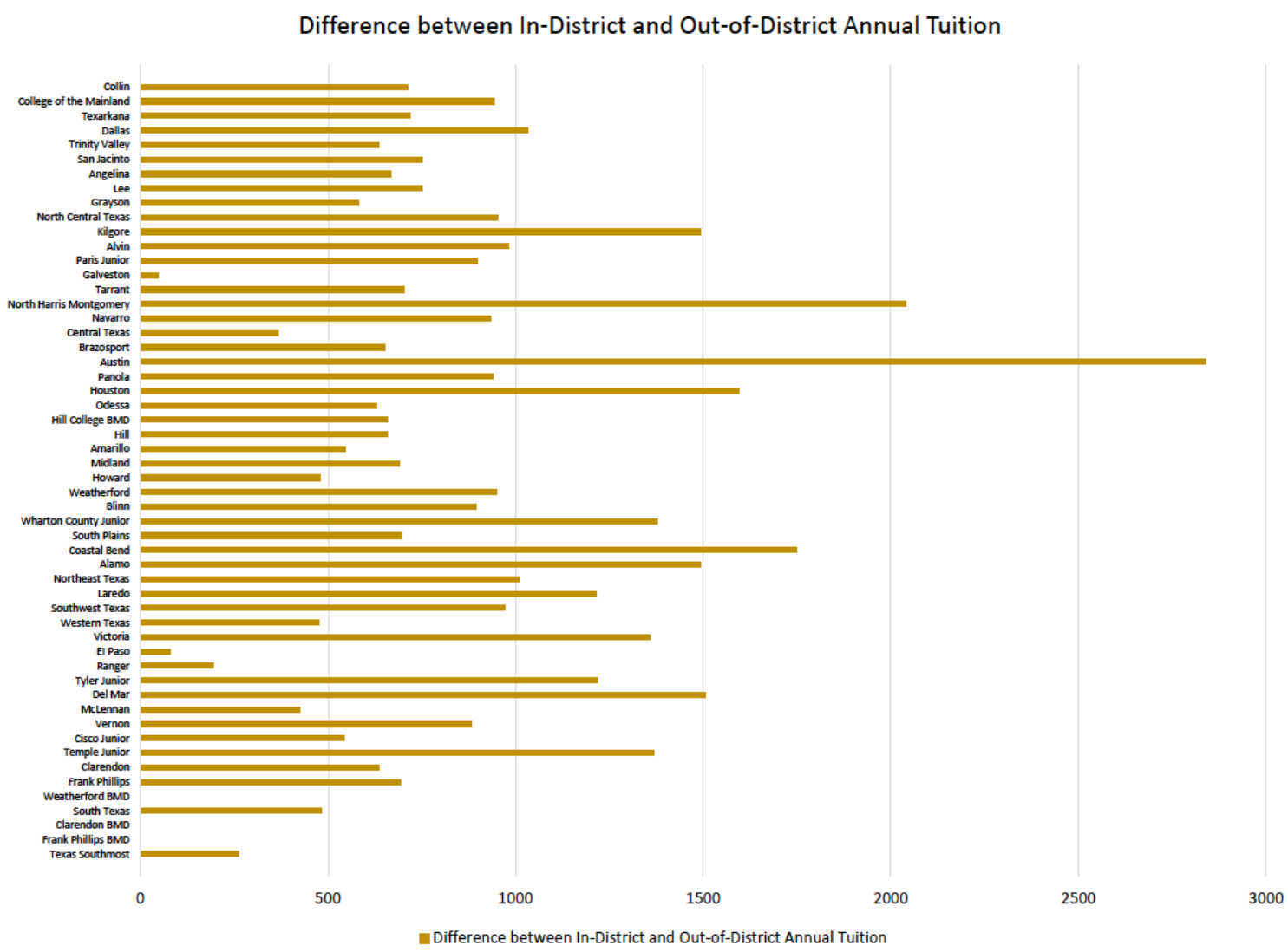


Table 1

Summary Statistics

1990 Census

2000 Census

2004-2010 ACS

\begin{tabular}{|c|c|c|c|c|c|c|}
\hline \multirow[b]{2}{*}{ Characteristics } & \multicolumn{2}{|c|}{1990 Census } & \multicolumn{2}{|c|}{2000 Census } & \multicolumn{2}{|c|}{ 2004-2010 ACS } \\
\hline & $\begin{array}{c}\text { Inside CTTD } \\
\text { (1) } \\
\end{array}$ & $\begin{array}{c}\text { Outside CCTD } \\
\text { (2) } \\
\end{array}$ & $\begin{array}{c}\text { Inside CTTD } \\
\text { (3) }\end{array}$ & $\begin{array}{c}\text { Outside CCTD } \\
(4) \\
\end{array}$ & $\begin{array}{c}\text { Inside CTTD } \\
\text { (5) }\end{array}$ & $\begin{array}{c}\text { Outside CCTD } \\
\text { (6) }\end{array}$ \\
\hline$\overline{\text { All }}$ & 50.78\% & $40.22 \%$ & $56.26 \%$ & 43.74\% & $63.11 \%$ & $36.89 \%$ \\
\hline Attend College 18-24 & $37.25 \%$ & $37.70 \%$ & $37.25 \%$ & $37.70 \%$ & $41.62 \%$ & $41.41 \%$ \\
\hline Attend College 18+ & $13.55 \%$ & $12.52 \%$ & $9.90 \%$ & $8.01 \%$ & $11.86 \%$ & $9.69 \%$ \\
\hline Attend Public College 18-24 & $45.15 \%$ & $46.88 \%$ & $32.23 \%$ & $34.11 \%$ & $36.22 \%$ & $37.12 \%$ \\
\hline Attend Public College 18+ & $11.35 \%$ & $11.02 \%$ & $8.55 \%$ & $7.11 \%$ & $10.19 \%$ & $8.47 \%$ \\
\hline Male & $44.86 \%$ & $46.06 \%$ & $45.86 \%$ & $46.51 \%$ & $48.71 \%$ & $47.92 \%$ \\
\hline Non-married & $21.80 \%$ & $18.34 \%$ & $22.62 \%$ & $17.34 \%$ & $22.24 \%$ & $28.14 \%$ \\
\hline Limitation & $9.85 \%$ & $10.18 \%$ & - & - & - & - \\
\hline Disabled & - & - & $22.49 \%$ & $22.17 \%$ & - & - \\
\hline \multicolumn{7}{|l|}{ Poverty Status } \\
\hline$<100 \%$ Poverty Level & $12.75 \%$ & $14.73 \%$ & $10.88 \%$ & $10.77 \%$ & $9.26 \%$ & $8.78 \%$ \\
\hline 100-199\% Poverty level & $16.72 \%$ & $18.96 \%$ & $18.44 \%$ & $18.79 \%$ & $18.26 \%$ & $16.45 \%$ \\
\hline 200-299\% Poverty level & $19.00 \%$ & $19.50 \%$ & $19.64 \%$ & $19.90 \%$ & $19.19 \%$ & $18.92 \%$ \\
\hline 300-399\% Poverty level & $16.53 \%$ & $16.20 \%$ & $15.99 \%$ & $16.33 \%$ & $16.04 \%$ & $16.59 \%$ \\
\hline 400-499\% Poverty level & $11.85 \%$ & $10.89 \%$ & $11.67 \%$ & $11.72 \%$ & $12.02 \%$ & $12.62 \%$ \\
\hline $500 \%$ and over Poverty level & $23.14 \%$ & $19.70 \%$ & $23.38 \%$ & $22.50 \%$ & $24.23 \%$ & $26.64 \%$ \\
\hline \multicolumn{7}{|l|}{ Race/Ethnicity } \\
\hline White & $78.46 \%$ & $86.02 \%$ & $57.08 \%$ & $74.05 \%$ & $50.24 \%$ & $69.26 \%$ \\
\hline Black & $13.82 \%$ & $7.15 \%$ & $12.74 \%$ & $7.95 \%$ & $12.87 \%$ & $8.20 \%$ \\
\hline Native American & $0.47 \%$ & $0.45 \%$ & $0.87 \%$ & $0.94 \%$ & $0.83 \%$ & $0.93 \%$ \\
\hline Asian American & $1.38 \%$ & $1.19 \%$ & $1.90 \%$ & $1.33 \%$ & $2.58 \%$ & $1.71 \%$ \\
\hline Hispanic & $5.62 \%$ & $5.16 \%$ & $26.98 \%$ & $15.41 \%$ & $32.83 \%$ & $19.43 \%$ \\
\hline Mixed & $0.06 \%$ & $0.04 \%$ & $0.42 \%$ & $0.32 \%$ & $0.65 \%$ & $0.46 \%$ \\
\hline \multicolumn{7}{|l|}{ Place of Birth } \\
\hline Born in Texas & $60.92 \%$ & $66.65 \%$ & $59.83 \%$ & $68.13 \%$ & $58.42 \%$ & $67.48 \%$ \\
\hline Born in U.S. Outside Texas & $32.61 \%$ & $28.70 \%$ & $28.40 \%$ & $26.01 \%$ & $26.68 \%$ & $24.91 \%$ \\
\hline Born Outside U.S. & $6.47 \%$ & $4.65 \%$ & $11.77 \%$ & $5.86 \%$ & $14.89 \%$ & $7.61 \%$ \\
\hline \multicolumn{7}{|l|}{ Migration Status } \\
\hline Migrated last 5 years & $50.85 \%$ & $46.87 \%$ & $47.94 \%$ & $44.42 \%$ & - & - \\
\hline Migrated Within Texas last 5 years & $42.19 \%$ & $39.85 \%$ & $39.01 \%$ & $37.96 \%$ & - & - \\
\hline Migrate Across Counties in Texas last 5 years & $12.91 \%$ & $16.55 \%$ & $10.39 \%$ & $16.10 \%$ & - & - \\
\hline Migrated in last year & - & - & - & - & $17.96 \%$ & $15.94 \%$ \\
\hline Migrated Within Texas in last year & - & - & - & - & $15.41 \%$ & $13.98 \%$ \\
\hline Migrate Across Counties in Texas last year & - & - & - & - & $3.61 \%$ & $5.03 \%$ \\
\hline \multicolumn{7}{|l|}{ Continuous Variables } \\
\hline Mean Age & 40.56 & 41.35 & 42.30 & 44.45 & 40.25 & 42.11 \\
\hline Mean Hours worked last year & 33.37 & 32.05 & 33.48 & 32.56 & 25.36 & 25.68 \\
\hline Mean Disability Rating & - & - & - & - & 0.02 & 0.02 \\
\hline Mean Tuition & 259.56 & 391.98 & 477.40 & 722.69 & 740.78 & 1278.55 \\
\hline Sample Size & 360,700 & 349,700 & 596,000 & 463,400 & 278,200 & 162,700 \\
\hline
\end{tabular}


Table 2

Linear Probability Estimates of Determinants College Enrollment in Texas

\begin{tabular}{|c|c|c|c|c|c|}
\hline \multicolumn{6}{|c|}{1990 Census Sample } \\
\hline \multirow[b]{3}{*}{ Variables } & \multicolumn{5}{|c|}{ (I) Enrollment in Any College } \\
\hline & \multicolumn{2}{|l|}{ Aged $18-24$} & \multicolumn{3}{|l|}{$\begin{array}{l}\text { Any College } \\
18 \text { and Older }\end{array}$} \\
\hline & $(1)$ & $(2)$ & (3) & $(4)$ & \\
\hline Tuition & $\begin{array}{l}-0.098^{* *} \\
(0.049)\end{array}$ & $\begin{array}{r}0.000 \\
(0.047)\end{array}$ & $\begin{array}{l}-0.073^{* * *} \\
(0.015)\end{array}$ & $\begin{array}{r}-0.033 \\
(0.015)\end{array}$ & $* *$ \\
\hline \multirow[t]{3}{*}{ Distance to closest CC main campus } & - & $\begin{array}{l}-0.008^{* * *} \\
(0.002)\end{array}$ & - & $\begin{array}{r}-0.004 \\
(0.001) \\
\end{array}$ & $* * *$ \\
\hline & \multicolumn{5}{|c|}{ (II) Enrollment in a Public College } \\
\hline & Aged 18 - 24 & & 18 and Older & & \\
\hline \multirow{3}{*}{$\frac{\text { Variables }}{\text { Tuition }}$} & (1) & $(2)$ & (3) & (4) & \\
\hline & -0.052 & 0.034 & $-0.060^{* * *}$ & -0.021 & \\
\hline & $(0.065)$ & $(0.057)$ & $(0.017)$ & $(0.016)$ & \\
\hline Distance to closest CC main campus & - & $\begin{array}{l}-0.007 * * * \\
(0.003)\end{array}$ & - & $\begin{array}{r}-0.003 \\
(0.001)\end{array}$ & $* * *$ \\
\hline \multicolumn{6}{|c|}{2000 Census Sample } \\
\hline & \multicolumn{5}{|c|}{ (I) Enrollment in Any College } \\
\hline & \multicolumn{2}{|c|}{ Aged $18-24$} & \multicolumn{3}{|c|}{ Aged 18 and Older } \\
\hline Variables & $(1)$ & $(2)$ & (3) & $(4)$ & \\
\hline Tuition & $\begin{array}{l}-0.122 * * * \\
(0.028)\end{array}$ & $\begin{array}{l}{ }^{-0.054^{* *}} \\
(0.028)\end{array}$ & $\begin{array}{l}-0.041 * * * \\
(0.007)\end{array}$ & $\begin{array}{r}-0.021 \\
(0.007)\end{array}$ & $* * *$ \\
\hline \multirow[t]{4}{*}{ Distance to closest CC main campus } & - & $\begin{array}{l}-0.013 * * * \\
(0.001)\end{array}$ & - & $\begin{array}{r}-0.004 \\
(0.000)\end{array}$ & $* * *$ \\
\hline & \multicolumn{5}{|c|}{ (II) Enrollment in a Public College } \\
\hline & \multicolumn{2}{|c|}{ Aged $18-24$} & \multicolumn{3}{|c|}{ Aged 18 and Older } \\
\hline & (1) & $(2)$ & (3) & $(4)$ & \\
\hline Tuition & $\begin{array}{l}-0.110 \text { *** } \\
(0.030)\end{array}$ & $\begin{array}{r}-0.048 \\
(0.030)\end{array}$ & $\begin{array}{l}-0.038^{* * *} \\
(0.008)\end{array}$ & $\begin{array}{r}-0.020 \\
(0.008)\end{array}$ & $* * *$ \\
\hline Distance to closest CC main campus & - & $\begin{array}{r}-0.012 \\
(0.001)\end{array}$ & - & $\begin{array}{r}-0.003 \\
(0.000)\end{array}$ & $* * *$ \\
\hline \multicolumn{6}{|c|}{ 2004-2010 ACS Sample } \\
\hline & \multicolumn{5}{|c|}{ (I) Enrollment in Any College } \\
\hline \multirow[b]{2}{*}{ Variables } & $18-24$ & & 18 and Older & & \\
\hline & $(1)$ & $(2)$ & (3) & $(4)$ & \\
\hline Tuition & $\begin{array}{l}-0.040 * * * \\
(0.013)\end{array}$ & $\begin{array}{r}-0.005 \\
(0.012)\end{array}$ & $\begin{array}{l}-0.014^{* * *} \\
(0.003)\end{array}$ & $\begin{array}{r}-0.003 \\
(0.003)\end{array}$ & \\
\hline \multirow[t]{3}{*}{ Distance to closest CC main campus } & - & $\begin{array}{l}-0.015 * * * \\
-0.002\end{array}$ & - & $\begin{array}{r}-0.004 \\
0.000\end{array}$ & $* * *$ \\
\hline & \multicolumn{5}{|c|}{ (II) Enrollment in a Public College } \\
\hline & $18-24$ & & 18 and Older & & \\
\hline Variables & \begin{tabular}{|r|}
$(1)$ \\
\end{tabular} & $(2)$ & (3) & (4) & \\
\hline $\begin{array}{l}\text { Tuition } \\
\end{array}$ & $\begin{array}{l}{ }^{-0.033^{* *}} \\
(0.014)\end{array}$ & $\begin{array}{r}-0.003 \\
(0.013)\end{array}$ & $\begin{array}{l}-0.013^{* * *} \\
(0.003)\end{array}$ & $\begin{array}{r}-0.003 \\
(0.003)\end{array}$ & \\
\hline Distance to closest CC main campus & - & $\begin{array}{l}-0.013 * * * \\
(0.002)\end{array}$ & - & $\begin{array}{r}-0.004 \\
(0.000)\end{array}$ & $* * *$ \\
\hline
\end{tabular}

Notes: Estimates also control for age, race, gender, race - gender interactions, place of birth, disability status, marital status, poverty level, migration status, weeks worked in the previous year, closest CCTD, and, for the ACS data, survey year. Standard errors are clustered at the Census tract level. 
Table 3a

Estimates of the Effect of Tuition on Enrollment by Race: 1990 Census Sample

\begin{tabular}{|c|c|c|c|c|}
\hline \multirow{3}{*}{ Race/Ethniclty } & \multicolumn{4}{|c|}{ (I) Enrollment in Any College } \\
\hline & \multicolumn{2}{|l|}{ Aged $18-24$} & \multicolumn{2}{|c|}{ Aged 18 and Older } \\
\hline & (1) & (2) & (3) & (4) \\
\hline \multirow[t]{2}{*}{ White } & $-0.114^{* *}$ & $\overline{-0.016}$ & $-0.082 * * *$ & $-0.041^{* * *}$ \\
\hline & $(0.050)$ & $(0.048)$ & $(0.015)$ & $(0.015)$ \\
\hline \multirow[t]{2}{*}{ Black } & -0.085 & 0.010 & $-0.043 *$ & -0.004 \\
\hline & $(0.074)$ & $(0.072)$ & $(0.023)$ & $(0.022)$ \\
\hline \multirow[t]{2}{*}{ Native American } & 0.140 & 0.248 & -0.071 & -0.031 \\
\hline & $(0.191)$ & (0.189) & $(0.050)$ & $(0.048)$ \\
\hline \multirow[t]{2}{*}{ Asian American } & -0.011 & 0.071 & -0.028 & 0.005 \\
\hline & $(0.085)$ & $(0.085)$ & $(0.037)$ & $(0.037)$ \\
\hline \multirow[t]{2}{*}{ Hispanic } & -0.032 & 0.093 & -0.005 & $0.046 *$ \\
\hline & $(0.062)$ & $(0.058)$ & $(0.024)$ & $(0.024)$ \\
\hline \multirow[t]{2}{*}{ Other/Mixed } & 0.489 & 0.593 & 0.149 & 0.184 \\
\hline & $(0.409)$ & $(0.410)$ & $(0.187)$ & $(0.188)$ \\
\hline \multirow[t]{2}{*}{ F-test } & 1.54 & $1.94^{*}$ & $4.36 * * *$ & $5.01^{* * *}$ \\
\hline & \multicolumn{4}{|c|}{ (II) Enrollment in a Public College } \\
\hline \multirow{2}{*}{ Race/Ethniclty } & Aged 18 - 24 & & d 18 and Olde & \\
\hline & (1) & (2) & (3) & (4) \\
\hline \multirow[t]{2}{*}{ White } & -0.061 & 0.024 & $-0.069^{* * *}$ & $-0.030 *$ \\
\hline & $(0.066)$ & $(0.058)$ & $(0.017)$ & $(0.016)$ \\
\hline \multirow[t]{2}{*}{ Black } & -0.063 & 0.020 & -0.032 & 0.005 \\
\hline & $(0.088)$ & $(0.080)$ & $(0.025)$ & $(0.023)$ \\
\hline \multirow[t]{2}{*}{ Native American } & 0.105 & 0.198 & -0.055 & -0.017 \\
\hline & $(0.190)$ & $(0.184)$ & $(0.046)$ & $(0.044)$ \\
\hline \multirow[t]{2}{*}{ Asian American } & 0.078 & 0.149 & 0.002 & 0.033 \\
\hline & $(0.107)$ & $(0.105)$ & $(0.040)$ & $(0.040)$ \\
\hline \multirow[t]{2}{*}{ Hispanic } & -0.013 & 0.095 & 0.003 & $0.052 * *$ \\
\hline & $(0.075)$ & $(0.066)$ & $(0.027)$ & $(0.026)$ \\
\hline \multirow[t]{2}{*}{ Other/Mixed } & 0.188 & 0.279 & 0.024 & 0.058 \\
\hline & $(0.483)$ & $(0.480)$ & (0.184) & (0.184) \\
\hline F-test & 0.87 & 1.02 & $3.88^{* * *}$ & $4.45^{* * *}$ \\
\hline
\end{tabular}

Notes: Linear probability estimates control for tuition and its interaction with race, age, race, gender, race - gender interactions, place of birth, disability status, marital status, poverty level, migration status, weeks worked in the previous year, and in columns (2) and (4) closest CCTD. Standard errors are clustered the census tract level. 
Table 3b

Estimates of the Effect of Tuition on Enrollment by Race: 2000 Census Sample

\begin{tabular}{|c|c|c|c|c|c|c|c|}
\hline \multirow{3}{*}{ Race/Ethniclty } & \multicolumn{7}{|c|}{ (I) Enrollment in Any College } \\
\hline & \multicolumn{3}{|c|}{ Aged $18-24$} & \multicolumn{4}{|c|}{ Aged 18 and Older } \\
\hline & (1) & & $(2)$ & (3) & & (4) & \\
\hline \multirow[t]{2}{*}{ White } & -0.099 & **** & -0.034 & -0.041 & *** & -0.022 & +*** \\
\hline & $(0.031)$ & & $(0.032)$ & $(0.008)$ & & $(0.008)$ & \\
\hline \multirow[t]{2}{*}{ Black } & -0.114 & $* * *$ & -0.051 & -0.040 & $* * *$ & -0.023 & $* *$ \\
\hline & $(0.039)$ & & $(0.039)$ & $(0.011)$ & & $(0.011)$ & \\
\hline \multirow[t]{2}{*}{ Native American } & -0.210 & $* * *$ & $-0.146 * *$ & -0.041 & $* * *$ & -0.022 & \\
\hline & $(0.069)$ & & $(0.070)$ & $(0.015)$ & & $(0.015)$ & \\
\hline \multirow[t]{2}{*}{ Asian American } & -0.112 & $* * *$ & $-0.076 * *$ & -0.015 & & -0.004 & \\
\hline & $(0.037)$ & & $(0.036)$ & $(0.015)$ & & $(0.015)$ & \\
\hline \multirow[t]{2}{*}{ Hispanic } & -0.168 & $* * *$ & $-0.092 * * *$ & -0.043 & $* * *$ & -0.022 & $* *$ \\
\hline & $(0.027)$ & & $(0.027)$ & $(0.009)$ & & $(0.009)$ & \\
\hline \multirow[t]{2}{*}{ Other/Mixed } & -0.109 & & -0.056 & -0.082 & $* * *$ & -0.066 & $* * *$ \\
\hline & $(0.087)$ & & $(0.088)$ & $(0.025)$ & & $(0.025)$ & \\
\hline \multirow[t]{2}{*}{ F-test } & 3.55 & $* * *$ & $2.35^{* *}$ & 1.51 & & 1.19 & \\
\hline & \multicolumn{7}{|c|}{ (II) Enrollment in a Public College } \\
\hline \multirow[t]{2}{*}{ Race/Ethniclty } & \multicolumn{3}{|c|}{ Aged 18 - 24} & \multicolumn{4}{|c|}{ Aged 18 and Older } \\
\hline & (1) & & $(2)$ & (3) & & (4) & \\
\hline \multirow[t]{2}{*}{ White } & -0.083 & ** & -0.023 & -0.038 & **** & -0.020 & ** \\
\hline & $(0.034)$ & & $(0.034)$ & $(0.008)$ & & $(0.008)$ & \\
\hline \multirow[t]{2}{*}{ Black } & -0.115 & $* * *$ & -0.057 & -0.041 & $* * *$ & -0.025 & $* *$ \\
\hline & $(0.040)$ & & $(0.040)$ & $(0.011)$ & & $(0.011)$ & \\
\hline \multirow[t]{2}{*}{ Native American } & -0.200 & $* * *$ & $-0.141 * *$ & -0.043 & $* * *$ & -0.025 & $*$ \\
\hline & $(0.066)$ & & $(0.067)$ & $(0.015)$ & & $(0.015)$ & \\
\hline \multirow[t]{2}{*}{ Asian American } & -0.044 & & -0.010 & 0.007 & & 0.016 & \\
\hline & (0.039) & & $(0.038)$ & $(0.016)$ & & $(0.012)$ & \\
\hline \multirow[t]{2}{*}{ Hispanic } & -0.168 & $* * *$ & $-0.098 * * *$ & -0.041 & $* * *$ & -0.021 & $* *$ \\
\hline & $(0.029)$ & & $(0.028)$ & $(0.009)$ & & $(0.009)$ & \\
\hline \multirow[t]{2}{*}{ Other/Mixed } & -0.111 & & -0.062 & -0.068 & $* * *$ & -0.053 & $* *$ \\
\hline & $(0.088)$ & & $(0.089)$ & $(0.024)$ & & $(0.024)$ & \\
\hline F-test & 6.29 & $* * *$ & $4.29^{* * *}$ & 2.46 & $* *$ & 1.98 & $*$ \\
\hline
\end{tabular}

Notes: Linear probability estimates control for tuition and its interaction with race, age, race, gender, race - gender interactions, place of birth, disability status, marital status, poverty level, migration status, weeks worked in the previous year, and in columns (2) and (4) closest CCTD. Standard errors are clustered at the census tract level. 
Table 3c

Estimates of the Effect of Tuition on Enrollment by Race: 2004-2010 ACS Sample

\begin{tabular}{|c|c|c|c|c|}
\hline \multirow{3}{*}{ Race/Ethniclty } & \multicolumn{4}{|c|}{ (I) Enrollment in Any College } \\
\hline & \multicolumn{2}{|l|}{ Aged 18 - 24} & \multicolumn{2}{|c|}{ Aged 18 and Older } \\
\hline & \begin{tabular}{|l|}
$(1)$ \\
\end{tabular} & (2) & (3) & (4) \\
\hline \multirow[t]{2}{*}{ White } & $-0.038^{* *}$ & -0.002 & $-0.015^{* * *}$ & -0.004 \\
\hline & $(0.016)$ & $(0.016)$ & $(0.003)$ & $(0.003)$ \\
\hline \multirow[t]{2}{*}{ Black } & -0.012 & 0.018 & -0.007 & -0.006 \\
\hline & $(0.023)$ & $(0.023)$ & $(0.006)$ & $(0.005)$ \\
\hline \multirow[t]{2}{*}{ Native American } & $-0.156 * *$ & $-0.116 *$ & $-0.030 * * *$ & $-0.019 *$ \\
\hline & $(0.061)$ & $(0.062)$ & $(0.011)$ & $(0.011)$ \\
\hline \multirow[t]{2}{*}{ Asian American } & $-0.059 * *$ & -0.040 & $-0.024 * * *$ & $-0.019 * *$ \\
\hline & $(0.027)$ & $(0.027)$ & $(0.008)$ & $(0.008)$ \\
\hline \multirow{2}{*}{ Hispanic } & $-0.044 * * *$ & -0.010 & $-0.012 * * *$ & -0.002 \\
\hline & $(0.012)$ & $(0.012)$ & $(0.004)$ & $(0.004)$ \\
\hline \multirow{2}{*}{ Other/Mixed } & -0.017 & 0.013 & $-0.029 *$ & -0.020 \\
\hline & $(0.071)$ & $(0.070)$ & $(0.017)$ & $(0.017)$ \\
\hline \multirow[t]{2}{*}{ F-test } & 1.46 & 1.52 & 1.61 & 1.74 \\
\hline & \multicolumn{4}{|c|}{ (II) Enrollment in a Public College } \\
\hline \multirow[t]{2}{*}{ Race/Ethniclty } & Aged 18 - 24 & & d 18 and Older & \\
\hline & (1) & (2) & (3) & (4) \\
\hline \multirow[t]{2}{*}{ White } & $-0.024 * * *$ & 0.008 & $-0.013 * * *$ & "-0.003 \\
\hline & $(0.017)$ & $(0.017)$ & $(0.003)$ & $(0.003)$ \\
\hline \multirow[t]{2}{*}{ Black } & -0.020 & 0.006 & $-0.009 *$ & -0.001 \\
\hline & $(0.022)$ & $(0.022)$ & $(0.005)$ & $(0.005)$ \\
\hline \multirow[t]{2}{*}{ Native American } & $-0.159 * * *$ & $-0.124 * *$ & $-0.033 * * *$ & $-0.023 * *$ \\
\hline & $(0.060)$ & $(0.061)$ & $(0.011)$ & $(0.011)$ \\
\hline \multirow[t]{2}{*}{ Asian American } & $-0.057 *$ & $-0.039 * *$ & $-0.023 * * *$ & $-0.017 * *$ \\
\hline & $(0.031)$ & $(0.031)$ & $(0.009)$ & $(0.009)$ \\
\hline \multirow[t]{2}{*}{ Hispanic } & $-0.045 * * *$ & $-0.015 *$ & $-0.013 * * *$ & -0.003 \\
\hline & $(0.012)$ & $(0.012)$ & $(0.004)$ & $(0.003)$ \\
\hline \multirow[t]{2}{*}{ Other/Mixed } & 0.029 & 0.056 & -0.017 & -0.009 \\
\hline & $(0.073)$ & $(0.072)$ & $(0.017)$ & $(0.017)$ \\
\hline F-test & 1.85 & $1.91 *$ & 1.19 & 1.46 \\
\hline
\end{tabular}

Notes: Linear probability estimates control for tuition and its interaction with race, age, race, gender, race - gender interactions, place of birth, disability status, marital status, poverty level, migration status, weeks worked in the previous year, and in columns (2) and (4) closest CCTD. Standard errors are clustered at the census tract level. 
Table 4a

Estimates of the Effect of Tuition on Enrollment by Gender: 1990 Census Sample

\begin{tabular}{|c|c|c|c|c|}
\hline \multirow{3}{*}{ Gender } & \multicolumn{4}{|c|}{ (I) Enrollment in Any College } \\
\hline & \multicolumn{2}{|l|}{ Aged 18 - 24} & \multicolumn{2}{|c|}{ Aged 18 and Older } \\
\hline & (1) & (2) & (3) & (4) \\
\hline \multirow[t]{2}{*}{ Female } & $-0.095 *$ & 0.003 & $-0.066^{* * *}$ & -0.025 \\
\hline & $(0.051)$ & $(0.050)$ & $(0.015)$ & $(0.015)$ \\
\hline \multirow[t]{2}{*}{ Male } & $-0.101 * *$ & -0.002 & $-0.079 * * *$ & $-0.039 * * *$ \\
\hline & $(0.051)$ & $(0.048)$ & $(0.015)$ & $(0.015)$ \\
\hline \multirow[t]{2}{*}{ F-test } & 0.05 & 0.04 & $3.7^{*}$ & $3.9^{* *}$ \\
\hline & \multicolumn{4}{|c|}{ (II) Enrollment in a Public College } \\
\hline \multirow[t]{2}{*}{ Gender } & \multicolumn{4}{|c|}{ Aged 18 and Older } \\
\hline & $(1)$ & (2) & (3) & (4) \\
\hline \multirow[t]{2}{*}{ Female } & -0.050 & 0.035 & $-0.050 * * *$ & -0.011 \\
\hline & $(0.065)$ & $(0.057)$ & $(0.018)$ & $(0.017)$ \\
\hline \multirow[t]{2}{*}{ Male } & -0.053 & -0.052 & $-0.069 * * *$ & $-0.030 *$ \\
\hline & $(0.068)$ & $(0.059)$ & (0.018) & $(0.016)$ \\
\hline F-test & 0.01 & 0.01 & $7.71 * * *$ & $7.99 * * *$ \\
\hline
\end{tabular}

Notes: Linear probability estimates control for tuition and its interaction with gender, age, race, gender, race - gender interactions, place of birth, disability status, marital status, poverty level, migration status, weeks worked in the previous year, and in columns (2) and (4) closest CCTD. Standard errors are clustered at the census tract level. 
Table 4b

Estimates of the Effect of Tuition on Enrollment by Gender: 2000 Census Sample

\begin{tabular}{|c|c|c|c|c|}
\hline \multirow{3}{*}{ Gender } & \multicolumn{4}{|c|}{ (I) Enrollment in Any College } \\
\hline & \multicolumn{2}{|c|}{ Aged $18-24$} & \multicolumn{2}{|c|}{ Aged 18 and Older } \\
\hline & (1) & (2) & (3) & (4) \\
\hline \multirow[t]{2}{*}{ Female } & $-0.117^{* * *}$ & $-0.049^{*}$ & $-0.041^{* * *}$ & $-0.022^{* * *}$ \\
\hline & $(0.028)$ & $(0.028)$ & $(0.007)$ & $(0.007)$ \\
\hline \multirow[t]{2}{*}{ Male } & $-0.126 * * *$ & $-0.060 * *$ & $-0.040 * * *$ & $-0.020 * * *$ \\
\hline & $(0.028)$ & $(0.028)$ & $(0.008)$ & $(0.008)$ \\
\hline \multirow[t]{2}{*}{ F-test } & 0.70 & 0.93 & 0.56 & 0.66 \\
\hline & \multicolumn{4}{|c|}{ (II) Enrollment in a Public College } \\
\hline \multirow[t]{2}{*}{ Gender } & \multicolumn{2}{|c|}{ Aged $18-24$} & \multicolumn{2}{|c|}{ Aged 18 and Older } \\
\hline & (1) & (2) & (3) & (4) \\
\hline \multirow[t]{2}{*}{ Female } & $-0.106 * * *$ & -0.043 & $-0.039 * * *$ & $-0.021 * * *$ \\
\hline & $(0.031)$ & $(0.031)$ & $(0.008)$ & $(0.008)$ \\
\hline \multirow[t]{2}{*}{ Male } & $-0.114 * * *$ & $-0.052 *$ & $-0.036 * * *$ & $-0.018 * *$ \\
\hline & $(0.030)$ & $(0.030)$ & $(0.008)$ & (0.008) \\
\hline F-test & 0.48 & 0.66 & 1.75 & 1.92 \\
\hline
\end{tabular}

Notes: Linear probability estimates control for tuition and its interaction with gender, age, race, gender, race gender interactions, place of birth, disability status, marital status, poverty level, migration status, weeks worked in the previous year, and in columns (2) and (4) closest CCTD. Standard errors are clustered at the census tract level. 
Table 4c

Estimates of the Effect of Tuition on Enrollment by Gender: 2004-2010 ACS Sample

\begin{tabular}{|c|c|c|c|c|}
\hline \multirow{3}{*}{ Gender } & \multicolumn{4}{|c|}{ (I) Enrollment in Any College } \\
\hline & \multicolumn{2}{|c|}{ Aged $18-24$} & \multicolumn{2}{|c|}{ Aged 18 and Older } \\
\hline & (1) & (2) & (3) & (4) \\
\hline \multirow[t]{2}{*}{ Female } & $-0.028^{* *}$ & 0.007 & $-0.012 * * *$ & -0.002 \\
\hline & $(0.013)$ & $(0.013)$ & $(0.003)$ & $(0.003)$ \\
\hline \multirow[t]{2}{*}{ Male } & $-0.051 * * *$ & -0.017 & $-0.016 * * *$ & $-0.005 *$ \\
\hline & $(0.009)$ & $(0.013)$ & $(0.003)$ & $(0.003)$ \\
\hline \multirow[t]{2}{*}{ F-test } & $6.98^{* * *}$ & $6.9^{* * *}$ & $3.72 *$ & $3.75 *$ \\
\hline & \multicolumn{4}{|c|}{ (II) Enrollment in a Public College } \\
\hline \multirow[t]{2}{*}{ Gender } & \multicolumn{2}{|c|}{ Aged $18-24$} & \multicolumn{2}{|c|}{ Aged 18 and Older } \\
\hline & $(1)$ & $(2)$ & (3) & (4) \\
\hline \multirow[t]{2}{*}{ Female } & $-0.028 * *$ & 0.002 & $-0.012 * * *$ & -0.003 \\
\hline & $(0.014)$ & $(0.014)$ & $(0.003)$ & $(0.003)$ \\
\hline \multirow[t]{2}{*}{ Male } & $-0.038 * * *$ & -0.008 & $-0.014 * * *$ & $-0.004 * *$ \\
\hline & $(0.014)$ & $(0.014)$ & $(0.003)$ & $(0.003)$ \\
\hline F-test & 1.34 & 1.29 & 0.57 & 0.57 \\
\hline
\end{tabular}

Notes: Linear probability estimates control for tuition and its interaction with gender, age, race, gender, race gender interactions, place of birth, disability status, marital status, poverty level, migration status, weeks worked in the previous year, and in columns (2) and (4) closest CCTD. Standard errors are clustered at the census tract level. 
Table 5a

Estimates of the Effect of Tuition on Enrollment by poverty Level: 1990 Census Sample

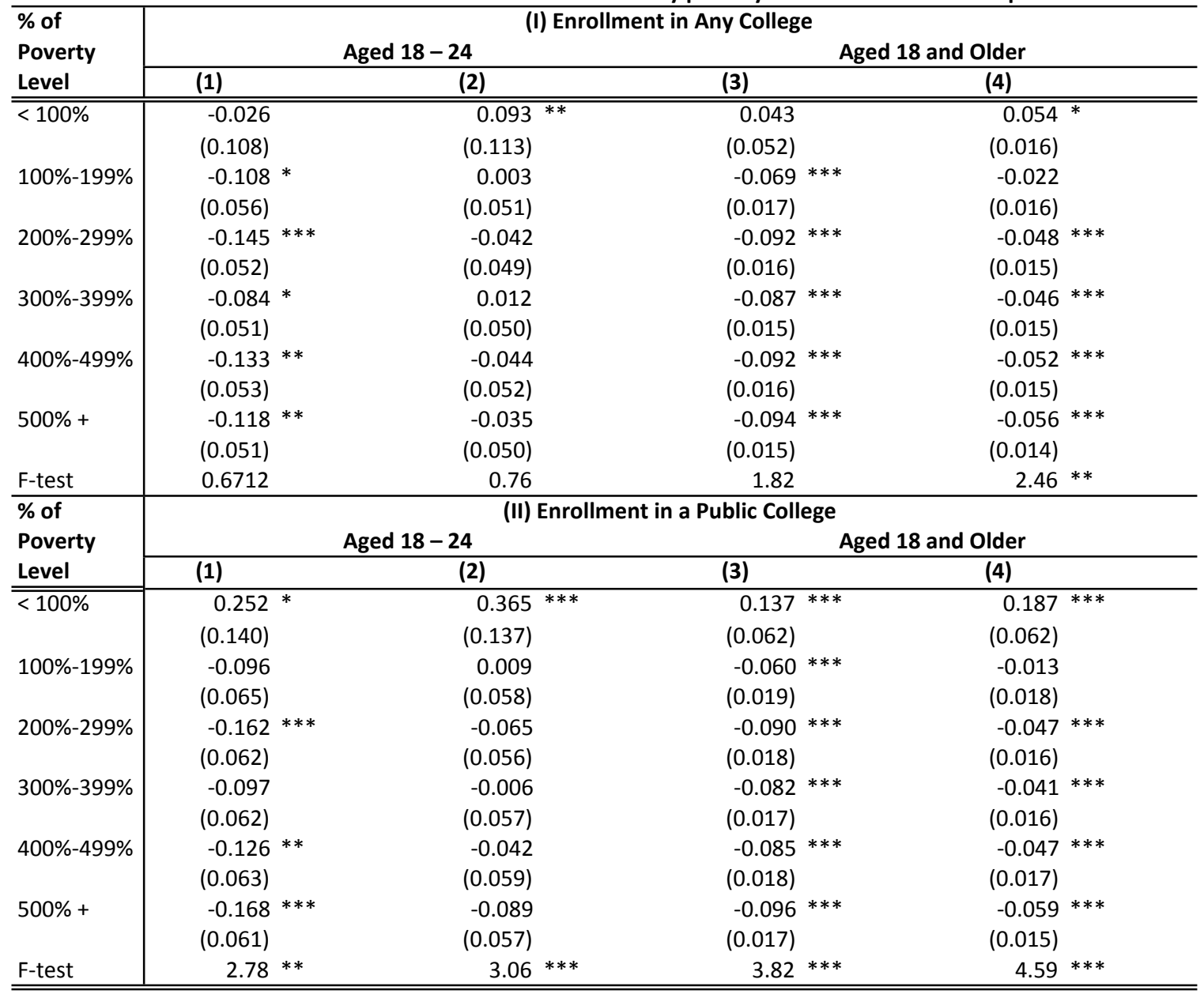

Notes: Linear probability estimates control for tuition and its interaction with poverty level, age, race, gender, race gender interactions, place of birth, disability status, marital status, poverty level, migration status, weeks worked in the previous year, and in columns (2) and (4) closest CCTD. Standard errors are clustered at the census tract level. 
Table 5b

Estimates of the Effect of Tuition on Enrollment by poverty Level: 2000 Census Sample

\begin{tabular}{|c|c|c|c|c|c|c|c|}
\hline \multirow{3}{*}{$\begin{array}{l}\% \text { of } \\
\text { Poverty } \\
\text { Level }\end{array}$} & \multicolumn{7}{|c|}{ (I) Enrollment in Any College } \\
\hline & \multicolumn{3}{|c|}{ Aged $18-24$} & \multicolumn{4}{|c|}{ Aged 18 and Older } \\
\hline & (1) & & (2) & (3) & & (4) & \\
\hline \multirow[t]{2}{*}{$\overline{<<100 \%}$} & 0.039 & & $0.112^{* *}$ & 0.064 & $\overline{* * *}$ & 0.086 & "*** \\
\hline & $(0.050)$ & & $(0.049)$ & $(0.025)$ & & $(0.025)$ & \\
\hline \multirow[t]{2}{*}{ 100\%-199\% } & -0.116 & $* * *$ & -0.038 & -0.030 & $* * *$ & -0.007 & \\
\hline & $(0.034)$ & & $(0.034)$ & $(0.010)$ & & $(0.010)$ & \\
\hline \multirow[t]{2}{*}{$200 \%-299 \%$} & -0.173 & $* * *$ & $-0.100 * * *$ & -0.053 & $* * *$ & -0.032 & $* * *$ \\
\hline & $(0.025)$ & & $(0.026)$ & $(0.007)$ & & $(0.007)$ & \\
\hline \multirow[t]{2}{*}{$300 \%-399 \%$} & -0.181 & $* * *$ & $-0.115 * * *$ & -0.056 & $* * *$ & -0.036 & $* * *$ \\
\hline & $(0.026)$ & & $(0.026)$ & $(0.007)$ & & $(0.007)$ & \\
\hline \multirow[t]{2}{*}{$400 \%-499 \%$} & -0.156 & $* * *$ & $-0.093 * * *$ & -0.056 & $* * *$ & -0.037 & $* * *$ \\
\hline & $(0.028)$ & & $(0.028)$ & $(0.007)$ & & $(0.007)$ & \\
\hline \multirow[t]{2}{*}{$500 \%+$} & -0.159 & $* * *$ & $-0.105 * * *$ & -0.055 & $* * *$ & -0.038 & $* * *$ \\
\hline & $(0.026)$ & & $(0.025)$ & $(0.007)$ & & $(0.007)$ & \\
\hline F-test & 7.90 & $* * *$ & $7.10 * * *$ & 5.90 & $* * *$ & 5.46 & $* * *$ \\
\hline$\%$ of & \multicolumn{7}{|c|}{ (II) Enrollment in a Public College } \\
\hline \multirow{2}{*}{$\begin{array}{l}\text { Poverty } \\
\text { Level }\end{array}$} & \multicolumn{3}{|c|}{ Aged $18-24$} & \multicolumn{4}{|c|}{ Aged 18 and Older } \\
\hline & (1) & & (2) & (3) & & (4) & \\
\hline \multirow[t]{2}{*}{$<<100 \%$} & 0.082 & & $0.150398^{* * *}$ & 0.075 & $* * *$ & 0.096 & $* * *$ \\
\hline & $(0.054)$ & & $(0.053)$ & $(0.026)$ & & $(0.026)$ & \\
\hline \multirow[t]{2}{*}{$100 \%-199 \%$} & -0.107 & $* * *$ & -0.035 & -0.028 & $* * *$ & -0.007 & \\
\hline & $(0.036)$ & & $(0.036)$ & $(0.010)$ & & $(0.010)$ & \\
\hline \multirow[t]{2}{*}{$200 \%-299 \%$} & -0.168 & $* * *$ & $-0.100 * * *$ & -0.050 & $* * *$ & -0.030 & $* * *$ \\
\hline & $(0.026)$ & & $(0.027)$ & $(0.007)$ & & $(0.008)$ & \\
\hline \multirow[t]{2}{*}{$300 \%-399 \%$} & -0.180 & $* * *$ & $-0.118 * * *$ & -0.053 & & -0.035 & $* * *$ \\
\hline & $(0.027)$ & & $(0.028)$ & $(0.007)$ & & $(0.007)$ & \\
\hline \multirow[t]{2}{*}{$400 \%-499 \%$} & -0.155 & $* * *$ & $-0.097 * * *$ & -0.054 & $* * *$ & -0.037 & $* * *$ \\
\hline & $(0.030)$ & & $(0.030)$ & $(0.008)$ & & $(0.008)$ & \\
\hline \multirow[t]{2}{*}{$500 \%+$} & -0.153 & $* * *$ & $-0.103 * * *$ & -0.052 & $* * *$ & -0.036 & $* * *$ \\
\hline & $(0.026)$ & & $(0.027)$ & $(0.007)$ & & $(0.007)$ & \\
\hline F-test & 9.26 & $* * *$ & $8.40 * * *$ & 6.29 & $* * *$ & 5.72 & $* * *$ \\
\hline
\end{tabular}

Notes: Linear probability estimates control for tuition and its interaction with poverty level, age, race, gender, race - gender interactions, place of birth, disability status, marital status, poverty level, migration status, weeks worked in the previous year, and in columns (2) and (4) closest CCTD. Standard errors are clustered at the census tract level. 
Table 5c

Estimates of the Effect of Tuition on Enrollment by poverty Level: 2004-2010 ACS Sample

\begin{tabular}{|c|c|c|c|c|c|c|c|}
\hline \multirow{3}{*}{$\%$ of Poverty Level } & \multicolumn{7}{|c|}{ (I) Enrollment in Any College } \\
\hline & \multicolumn{3}{|c|}{ Aged $18-24$} & \multicolumn{4}{|c|}{ Aged 18 and Older } \\
\hline & (1) & & (2) & (3) & & (4) & \\
\hline \multirow[t]{2}{*}{$<<100 \%$} & 0.045 & * & $0.083 * * *$ & 0.024 & * & 0.035 & ;*** \\
\hline & $(0.027)$ & & $(0.027)$ & $(0.013)$ & & $(0.013)$ & \\
\hline \multirow[t]{2}{*}{$100 \%-199 \%$} & -0.042 & $* * *$ & -0.006 & -0.009 & $* *$ & 0.002 & \\
\hline & $(0.015)$ & & $(0.014)$ & $(0.004)$ & & $(0.004)$ & \\
\hline \multirow[t]{2}{*}{$200 \%-299 \%$} & -0.059 & $* * *$ & $-0.024 *$ & 0.018 & $* * *$ & -0.007 & $* *$ \\
\hline & $(0.013)$ & & $(0.001)$ & $(0.003)$ & & $(0.003)$ & \\
\hline \multirow[t]{2}{*}{$300 \%-399 \%$} & -0.066 & $* *$ & $-0.032 * *$ & -0.018 & $* * *$ & -0.007 & $7 *$ \\
\hline & $(0.014)$ & & $(0.014)$ & $(0.003)$ & & $(0.003)$ & \\
\hline \multirow[t]{2}{*}{$400 \%-499 \%$} & -0.086 & $* * *$ & $-0.052 * * *$ & -0.020 & $* * *$ & -0.010 & $* * *$ \\
\hline & $(0.017)$ & & $(0.017)$ & $(0.003)$ & & $(0.003)$ & \\
\hline \multirow[t]{2}{*}{$500 \%+$} & -0.063 & $* * *$ & $-0.033 * *$ & -0.021 & $* * *$ & -0.011 & $* * *$ \\
\hline & $(0.015)$ & & $(0.014)$ & $(0.003)$ & & $(0.003)$ & \\
\hline \multirow[t]{2}{*}{ F-test } & 4.82 & $* * *$ & $4.99 * * *$ & 3.4 & $* * *$ & 3.58 & $* * *$ \\
\hline & \multicolumn{7}{|c|}{ (II) Enrollment in a Public College } \\
\hline \multirow[t]{2}{*}{$\%$ of Poverty Level } & \multicolumn{3}{|c|}{ Aged $18-24$} & \multicolumn{4}{|c|}{ Aged 18 and Older } \\
\hline & (1) & & (2) & (3) & & (4) & \\
\hline \multirow[t]{2}{*}{$\overline{<<100 \%}$} & 0.064 & $* *$ & $0.098^{* * *}$ & 0.032 & $* *$ & 0.042 & $* * *$ \\
\hline & (0.029) & & $(0.028)$ & $(0.013)$ & & $(0.013)$ & \\
\hline \multirow[t]{2}{*}{$100 \%-199 \%$} & -0.040 & $* * *$ & -0.008 & -0.008 & $* *$ & 0.002 & \\
\hline & $(0.015)$ & & $(0.015)$ & $(0.004)$ & & $(0.004)$ & \\
\hline \multirow[t]{2}{*}{ 200\%-299\% } & -0.055 & $* * *$ & $-0.023 *$ & -0.018 & $* * *$ & -0.008 & $3 * *$ \\
\hline & $(0.013)$ & & $(0.014)$ & $(0.003)$ & & $(0.003)$ & \\
\hline \multirow[t]{2}{*}{ 300\%-399\% } & -0.063 & $* * *$ & $-0.033 * *$ & -0.019 & $* * *$ & -0.010 & $* * *$ \\
\hline & $(0.014)$ & & $(0.015)$ & $(0.003)$ & & $(0.003)$ & \\
\hline \multirow[t]{2}{*}{$400 \%-499 \%$} & -0.077 & $* * *$ & $-0.047 * * *$ & -0.019 & $* * *$ & -0.009 & $* * *$ \\
\hline & $(0.017)$ & & $(0.017)$ & $(0.003)$ & & $(0.003)$ & \\
\hline \multirow[t]{2}{*}{$500 \%+$} & -0.062 & $* * *$ & $-0.035 * *$ & -0.020 & $* * *$ & -0.011 & L** \\
\hline & $(0.015)$ & & $(0.015)$ & $(0.003)$ & & (0.003) & \\
\hline F-test & 5.62 & $* * *$ & $5.76^{* * *}$ & 3.81 & $* * *$ & 3.86 & $* * *$ \\
\hline
\end{tabular}

Notes: Linear probability estimates control for tuition and its interaction with poverty level, age, race, gender, race gender interactions, place of birth, disability status, marital status, poverty level, migration status, weeks worked in the previous year, and in columns (2) and (4) closest CCTD. Standard errors are clustered at the census tract level. 
Table 6

Linear Probability Estimates of Determinants College Enrollment in Texas

1990 Census

\begin{tabular}{|c|c|c|c|c|c|}
\hline \multirow{4}{*}{ Variables } & & & & & \\
\hline & \multicolumn{5}{|c|}{ (I) Enrollment in Any College } \\
\hline & \multicolumn{2}{|c|}{ Aged 18 - 24} & \multicolumn{3}{|c|}{ Aged 18 and Older } \\
\hline & $(1)$ & $(2)$ & (3) & (4) & \\
\hline \multirow[t]{2}{*}{ High Subsidy } & $0.034 *$ & $0.046^{* *}$ & $0.014^{* * *}$ & 0.021 & $* * *$ \\
\hline & $(0.018)$ & $(0.019)$ & $(0.005)$ & $(0.006)$ & \\
\hline \multirow[t]{2}{*}{ In CCTD } & -0.001 & $-0.039 * *$ & 0.005 & -0.011 & $* *$ \\
\hline & $(0.014)$ & $(0.016)$ & $(0.004)$ & $(0.005)$ & \\
\hline \multirow[t]{3}{*}{ Distance to closest CC main campus } & & $-0.011 * * *$ & & -0.005 & $* * *$ \\
\hline & & $(0.003)$ & & $(0.001)$ & \\
\hline & \multicolumn{5}{|c|}{ (II) Enrollment in a Public College } \\
\hline \multirow[t]{2}{*}{ Variables } & \multicolumn{2}{|c|}{ Aged 18 - 24} & \multicolumn{3}{|c|}{ Aged 18 and Older } \\
\hline & $(1)$ & $(2)$ & (3) & (4) & \\
\hline \multirow[t]{2}{*}{ High Subsidy } & $0.050 * *$ & $0.062 * *$ & $0.016^{* * *}$ & 0.023 & $* * *$ \\
\hline & $(0.025)$ & $(0.026)$ & $(0.006)$ & $(0.007)$ & \\
\hline \multirow[t]{2}{*}{ In CCTD } & -0.021 & $-0.058 * * *$ & 0.001 & -0.015 & $* * *$ \\
\hline & $(0.018)$ & $(0.020)$ & $(0.005)$ & $(0.006)$ & \\
\hline \multirow[t]{2}{*}{ Distance to closest CC main campus } & & $-0.011 * * *$ & & -0.005 & $* * *$ \\
\hline & & $(0.003)$ & & $(0.001)$ & \\
\hline
\end{tabular}

\begin{tabular}{|c|c|c|c|c|c|c|c|}
\hline \multirow{3}{*}{ Variables } & \multicolumn{7}{|c|}{ (I) Enrollment in Any College } \\
\hline & \multicolumn{4}{|c|}{ Aged $18-24$} & \multicolumn{3}{|c|}{ Aged 18 and Older } \\
\hline & $(1)$ & & $(2)$ & & (3) & (4) & \\
\hline \multirow[t]{2}{*}{ High Subsidy } & 0.049 & $* * *$ & 0.069 & $* * *$ & $0.014^{* * *}$ & 0.019 & $* * *$ \\
\hline & $(0.015)$ & & $(0.006)$ & & $(0.001)$ & $(0.003)$ & \\
\hline \multirow[t]{2}{*}{ In CCTD } & 0.013 & & -0.034 & $* * *$ & $0.005 * * *$ & -0.008 & $* * *$ \\
\hline & $(0.011)$ & & $(0.005)$ & & $(0.001)$ & $(0.003)$ & \\
\hline \multirow[t]{2}{*}{ Distance to closest CC main campus } & & & -0.015 & $* * *$ & & -0.004 & $* * *$ \\
\hline & & & $(0.001)$ & & & $(0.000)$ & \\
\hline & \multicolumn{7}{|c|}{ (II) Enrollment in a Public College } \\
\hline \multirow[t]{2}{*}{ Variables } & \multicolumn{4}{|c|}{ Aged 18 - 24} & \multicolumn{3}{|c|}{ Aged 18 and Older } \\
\hline & $(1)$ & & $(2)$ & & (3) & (4) & \\
\hline \multirow[t]{2}{*}{ High Subsidy } & 0.054 & $* * *$ & 0.073 & $* * *$ & $0.014^{* * *}$ & 0.019 & $* * *$ \\
\hline & $(0.016)$ & & $(0.016)$ & & $(0.004)$ & $(0.004)$ & \\
\hline \multirow[t]{2}{*}{ In CCTD } & 0.003 & & -0.044 & $* * *$ & 0.003 & -0.009 & $* * *$ \\
\hline & $(0.012)$ & & $(0.012)$ & & $(0.003)$ & $(0.003)$ & \\
\hline \multirow[t]{2}{*}{ Distance to closest CC main campus } & & & -0.015 & $* * *$ & & -0.004 & $* * *$ \\
\hline & & & $(0.002)$ & & & $(0.000)$ & \\
\hline
\end{tabular}

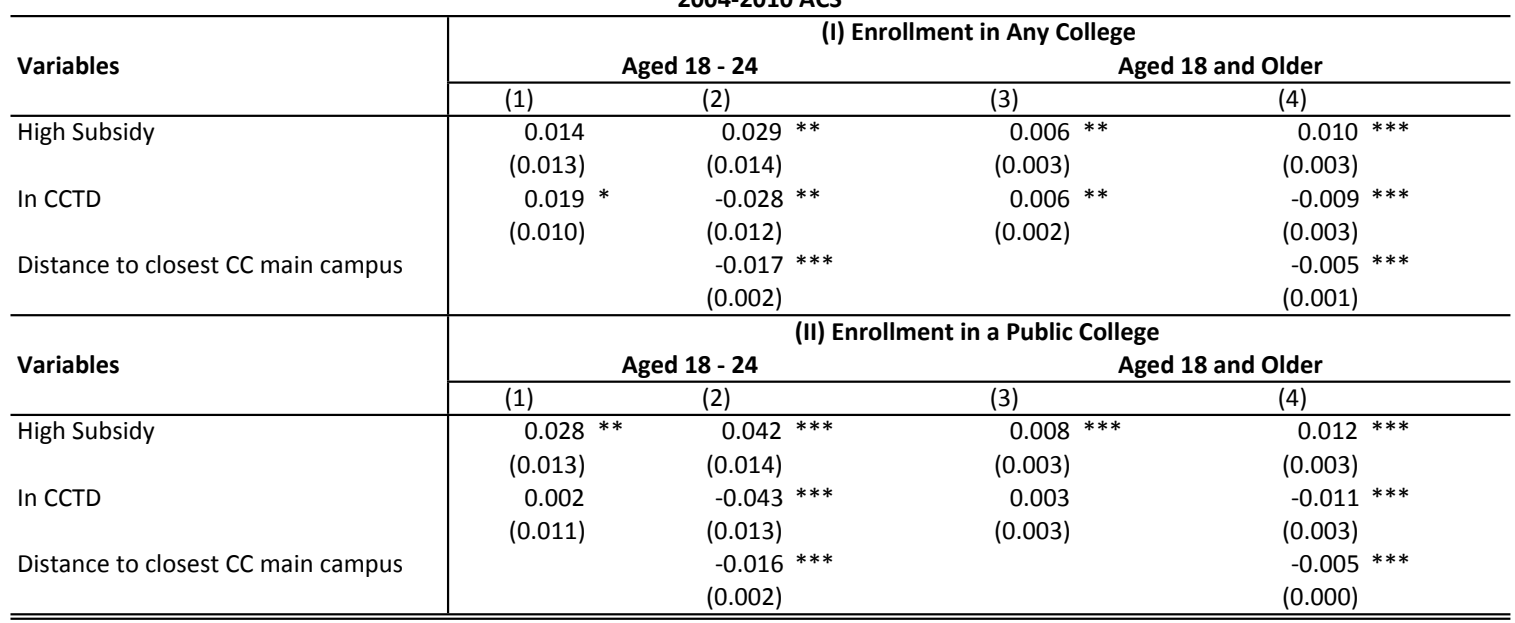

Notes: Estimates also control for age, race, gender, race - gender interactions, place of birth, disability status, marital status, poverty level, migration status, weeks worked in the previous year, closest CCTD, and, for the ACS data, survey year. Standard errors are clustered at the Census tract level. 
Table 7a

Estimates of the Effect of High Subsidy on Enrollment by Race: 1990 Census

\begin{tabular}{|c|c|c|c|c|c|}
\hline \multirow{3}{*}{ Race/Ethnicity } & \multicolumn{5}{|c|}{ (I) Enrollment in Any College } \\
\hline & \multicolumn{2}{|l|}{ Aged 18 - 24} & \multicolumn{3}{|l|}{ Aged 18 and Older } \\
\hline & (1) & (2) & (3) & (4) & \\
\hline \multirow[t]{2}{*}{ White } & $0.032^{*}$ & $0.044^{* *}$ & $0.013^{* *}$ & 0.019 & "*** \\
\hline & (0.019) & $(0.020)$ & $(0.006)$ & $(0.006)$ & \\
\hline \multirow[t]{2}{*}{ Black } & $0.043 *$ & $0.058 * * *$ & $0.020 * * *$ & 0.028 & $* * *$ \\
\hline & $(0.022)$ & $(0.023)$ & $(0.006)$ & $(0.007)$ & \\
\hline \multirow[t]{2}{*}{ Native American } & 0.002 & 0.015 & 0.014 & 0.021 & \\
\hline & $(0.051)$ & $(0.051)$ & $(0.016)$ & $(0.016)$ & \\
\hline \multirow[t]{2}{*}{ Asian American } & $0.082 * *$ & $0.095 * *$ & $0.048 * *$ & 0.055 & $* * *$ \\
\hline & $(0.037)$ & $(0.038)$ & $(0.020)$ & $(0.020)$ & \\
\hline \multirow[t]{2}{*}{ Hispanic } & 0.029 & $0.044 *$ & $0.019 * *$ & 0.027 & $* * *$ \\
\hline & $(0.022)$ & $(0.022)$ & $(0.008)$ & $(0.008)$ & \\
\hline \multirow[t]{2}{*}{ Other/Mixed } & $x x x x$ & $x x x x$ & $x x x x$ & $x x x x$ & \\
\hline & $x x x x$ & $x x x x$ & $x x x x$ & $x x x x$ & \\
\hline \multirow[t]{2}{*}{ F-test } & 0.73 & 0.79 & 1.33 & 1.61 & \\
\hline & \multicolumn{5}{|c|}{ (II) Enrollment in a Public College } \\
\hline \multirow[t]{2}{*}{ Race/Ethnicity } & \multicolumn{2}{|l|}{ Aged 18 - 24} & \multicolumn{3}{|l|}{ Aged 18 and Older } \\
\hline & (1) & (2) & (3) & (4) & \\
\hline \multirow[t]{2}{*}{ White } & $0.051^{* *}$ & $0.062^{* *}$ & $0.015^{* *}$ & 0.022 & $* * *$ \\
\hline & $(0.026)$ & $(0.027)$ & $(0.007)$ & $(0.007)$ & \\
\hline \multirow[t]{2}{*}{ Black } & 0.036 & $0.051 *$ & $0.017 * * *$ & 0.026 & $* * *$ \\
\hline & $(0.026)$ & $(0.027)$ & $(0.007)$ & $(0.007)$ & \\
\hline \multirow[t]{2}{*}{ Native American } & 0.010 & 0.023 & 0.008 & 0.015 & \\
\hline & $(0.054)$ & $(0.054)$ & $(0.015)$ & $(0.015)$ & \\
\hline \multirow[t]{2}{*}{ Asian American } & $0.148 * * *$ & $0.161 * * *$ & $0.071 * * *$ & 0.079 & $* * *$ \\
\hline & $(0.053)$ & $(0.054)$ & $(0.024)$ & $(0.024)$ & \\
\hline \multirow[t]{2}{*}{ Hispanic } & 0.034 & $0.048 *$ & $0.018 * *$ & 0.026 & $* * *$ \\
\hline & $(0.027)$ & $(0.027)$ & $(0.008)$ & $(0.009)$ & \\
\hline \multirow[t]{2}{*}{ Other/Mixed } & $x x x x$ & $x x x x$ & $x x x x$ & $x x x x$ & \\
\hline & $x x x x$ & $x x x x$ & $x x x x$ & $x x x x$ & \\
\hline F-test & 0.1661 & 1.53 & $1.91 *$ & 2.1 & $*$ \\
\hline
\end{tabular}

Notes: Linear probability estimates control for in-district status and high subsidy receipt and their interaction with race, age, race, gender, race - gender interactions, place of birth, disability status, marital status, poverty level, migration status, weeks worked in the previous year, and in columns (2) and (4) closest CCTD. Standard errors are clustered at the census tract level. 
Table 7b

Estimates of the Effect of High Subsidy on Enrollment by Race: 2000 Census

\begin{tabular}{|c|c|c|c|c|c|c|}
\hline \multirow{3}{*}{ Race/Ethnicity } & \multicolumn{6}{|c|}{ (I) Enrollment in Any College } \\
\hline & \multicolumn{2}{|l|}{ Aged 18 - 24} & \multicolumn{4}{|c|}{ Aged 18 and Older } \\
\hline & (1) & (2) & (3) & & (4) & \\
\hline \multirow[t]{2}{*}{ White } & $0.058 * * *$ & $0.075 * * *$ & 0.016 & *** & 0.020 & *** \\
\hline & (0.017) & $(0.017)$ & $(0.004)$ & & $(0.004)$ & \\
\hline \multirow[t]{2}{*}{ Black } & $0.034 *$ & $0.054 * * *$ & 0.009 & $* *$ & 0.014 & $* * *$ \\
\hline & $(0.018)$ & $(0.018)$ & $(0.004)$ & & $(0.004)$ & \\
\hline \multirow[t]{2}{*}{ Native American } & 0.021 & 0.040 & 0.018 & $* *$ & 0.023 & $* * *$ \\
\hline & $(0.038)$ & $(0.038)$ & $(0.008)$ & & $(0.008)$ & \\
\hline \multirow[t]{2}{*}{ Asian American } & $0.073 * * *$ & $0.090 * * *$ & 0.038 & $* * *$ & 0.043 & $* * *$ \\
\hline & $(0.025)$ & $(0.025)$ & $(0.010)$ & & $(0.010)$ & \\
\hline \multirow[t]{2}{*}{ Hispanic } & $0.037 * * *$ & $0.058 * * *$ & 0.003 & & 0.009 & $* *$ \\
\hline & $(0.014)$ & $(0.014)$ & $(0.004)$ & & $(0.004)$ & \\
\hline \multirow[t]{2}{*}{ Other/Mixed } & 0.057 & 0.073 & 0.046 & $* * *$ & 0.050 & $* * *$ \\
\hline & $(0.049)$ & $(0.049)$ & $(0.015)$ & & $(0.015)$ & \\
\hline \multirow[t]{2}{*}{ F-test } & 1.53 & 1.08 & 5.89 & $* * *$ & 5.1 & $* * *$ \\
\hline & \multicolumn{6}{|c|}{ (II) Enrollment in a Public College } \\
\hline \multirow[t]{2}{*}{ Race/Ethnicity } & Aged 18 - 24 & & d 18 and & Older & & \\
\hline & (1) & (2) & (3) & & (4) & \\
\hline \multirow[t]{2}{*}{ White } & $0.063 * * *$ & $0.079 * * *$ & 0.017 & $* * *$ & 0.021 & $* * *$ \\
\hline & $(0.018)$ & $(0.018)$ & $(0.004)$ & & $(0.004)$ & \\
\hline \multirow[t]{2}{*}{ Black } & $0.035 *$ & $0.054 * * *$ & 0.009 & $* *$ & 0.014 & $* * *$ \\
\hline & $(0.018)$ & $(0.018)$ & $(0.004)$ & & $(0.004)$ & \\
\hline \multirow[t]{2}{*}{ Native American } & 0.031 & 0.049 & 0.017 & $* *$ & 0.022 & $* * *$ \\
\hline & $(0.038)$ & $(0.038)$ & $(0.008)$ & & $(0.008)$ & \\
\hline \multirow[t]{2}{*}{ Asian American } & $0.090 * * *$ & $0.107 * * *$ & 0.041 & $* * *$ & 0.046 & $* * *$ \\
\hline & $(0.028)$ & $(0.028)$ & $(0.011)$ & & $(0.011)$ & \\
\hline \multirow[t]{2}{*}{ Hispanic } & $0.038 * *$ & $0.059 * * *$ & 0.004 & & 0.009 & $* *$ \\
\hline & $(0.015)$ & $(0.015)$ & $(0.004)$ & & $(0.004)$ & \\
\hline \multirow[t]{2}{*}{ Other/Mixed } & 0.063 & 0.079 & 0.047 & $* * *$ & 0.052 & $* * *$ \\
\hline & $(0.050)$ & $(0.050)$ & $(0.014)$ & & $(0.014)$ & \\
\hline F-test & $1.98 *$ & $1.53 * *$ & 7.04 & $* * *$ & 6.07 & $* * *$ \\
\hline
\end{tabular}

Notes: Linear probability estimates control for in-district status and high subsidy receipt and their interaction with race, age, race, gender, race - gender interactions, place of birth, disability status, marital status, poverty level, migration status, weeks worked in the previous year, and in columns (2) and (4) closest CCTD. Standard errors are clustered at the census tract level. 
Table 7c

Estimates of the Effect of High Subsidy on Enrollment by Race: 2004-2010 ACS

\begin{tabular}{|c|c|c|c|c|c|}
\hline \multirow{3}{*}{ Race/Ethnicity } & \multicolumn{5}{|c|}{ (I) Enrollment in Any College } \\
\hline & \multicolumn{2}{|l|}{ Aged 18 - 24} & \multicolumn{3}{|c|}{ Aged 18 and Older } \\
\hline & (1) & (2) & (3) & (4) & \\
\hline \multirow[t]{2}{*}{ White } & $0.030^{* * *}$ & $0.045^{* * *}$ & $0.009^{* * *}$ & 0.013 & "*** \\
\hline & $(0.009)$ & $(0.009)$ & $(0.002)$ & $(0.002)$ & \\
\hline \multirow[t]{2}{*}{ Black } & 0.010 & $0.026 *$ & 0.001 & 0.007 & $*$ \\
\hline & $(0.015)$ & $(0.015)$ & $(0.004)$ & $(0.004)$ & \\
\hline \multirow[t]{2}{*}{ Native American } & -0.005 & 0.008 & 0.008 & 0.013 & \\
\hline & $(0.053)$ & $(0.053)$ & $(0.013)$ & $(0.013)$ & \\
\hline \multirow[t]{2}{*}{ Asian American } & 0.030 & $0.043 *$ & 0.012 & 0.016 & $*$ \\
\hline & $(0.025)$ & $(0.025)$ & $(0.008)$ & $(0.008)$ & \\
\hline \multirow[t]{2}{*}{ Hispanic } & -0.011 & 0.004 & 0.000 & 0.005 & \\
\hline & $(0.010)$ & $(0.010)$ & $(0.003)$ & $(0.003)$ & \\
\hline \multirow[t]{2}{*}{ Other/Mixed } & -0.006 & 0.008 & -0.012 & -0.007 & \\
\hline & $(0.055)$ & $(0.055)$ & $(0.017)$ & $(0.017)$ & \\
\hline \multirow[t]{2}{*}{ F-test } & $3.38^{* * *}$ & $3.2^{* * *}$ & $2.58^{* *}$ & 2.42 & $* *$ \\
\hline & \multicolumn{5}{|c|}{ (II) Enrollment in a Public College } \\
\hline \multirow{2}{*}{ Race/Ethnicity } & Aged 18 - 24 & & d 18 and Older & & \\
\hline & (1) & $(2)$ & (3) & (4) & \\
\hline \multirow[t]{2}{*}{ White } & $0.045^{* * *}$ & $0.058 * * *$ & $0.011^{* * *}$ & 0.015 & $* * *$ \\
\hline & $(0.009)$ & $(0.009)$ & $(0.002)$ & $(0.002)$ & \\
\hline \multirow[t]{2}{*}{ Black } & 0.019 & $0.033 * *$ & 0.002 & 0.007 & $*$ \\
\hline & $(0.014)$ & $(0.015)$ & $(0.004)$ & $(0.004)$ & \\
\hline \multirow[t]{2}{*}{ Native American } & 0.019 & 0.031 & 0.013 & 0.017 & \\
\hline & $(0.052)$ & $(0.052)$ & $(0.012)$ & $(0.012)$ & \\
\hline \multirow[t]{2}{*}{ Asian American } & $0.075 * * *$ & $0.086 * * *$ & $0.021 * *$ & 0.025 & $* * *$ \\
\hline & $(0.027)$ & $(0.027)$ & $(0.008)$ & $(0.008)$ & \\
\hline \multirow[t]{2}{*}{ Hispanic } & -0.003 & 0.012 & 0.001 & 0.006 & $* *$ \\
\hline & $(0.010)$ & $(0.010)$ & $(0.003)$ & $(0.003)$ & \\
\hline \multirow[t]{2}{*}{ Other/Mixed } & 0.054 & 0.068 & 0.002 & 0.006 & \\
\hline & $(0.054)$ & $(0.054)$ & $(0.016)$ & $(0.016)$ & \\
\hline F-test & $5.23^{* * *}$ & $4.97^{* * *}$ & $3.74^{* * *}$ & 3.51 & $* * *$ \\
\hline
\end{tabular}


Table 8a

Estimates of the Effect of High Subsidy on Enrollment by Gender: 1990 Census

\begin{tabular}{|c|c|c|c|c|}
\hline \multirow{3}{*}{ Gender } & \multicolumn{4}{|c|}{ (I) Enrollment in Any College } \\
\hline & \multicolumn{2}{|c|}{ Aged $18-24$} & \multicolumn{2}{|c|}{ Aged 18 and Older } \\
\hline & (1) & $(2)$ & (3) & (4) \\
\hline \multirow[t]{2}{*}{ Female } & $0.040 * *$ & $0.052^{* * *}$ & $0.015^{* * *}$ & $0.022 * * *$ \\
\hline & $(0.019)$ & $(0.020)$ & $(0.005)$ & $(0.006)$ \\
\hline \multirow[t]{2}{*}{ Male } & 0.029 & $0.041 * *$ & $0.013 * *$ & $0.020 * * *$ \\
\hline & (0.019) & $(0.020)$ & $(0.005)$ & $(0.006)$ \\
\hline \multirow[t]{2}{*}{ F-test } & 1.700 & 1.700 & 0.670 & 0.610 \\
\hline & \multicolumn{4}{|c|}{ (II) Enrollment in a Public College } \\
\hline \multirow[t]{2}{*}{ Gender } & Aged $18-24$ & & d 18 and Olde & \\
\hline & $(1)$ & $(2)$ & (3) & (4) \\
\hline \multirow[t]{2}{*}{ Female } & $0.048^{* *}$ & $0.060^{* *}$ & $0.016^{* *}$ & $0.023^{* * *}$ \\
\hline & $(0.025)$ & $(0.026)$ & $(0.007)$ & $(0.007)$ \\
\hline \multirow[t]{2}{*}{ Male } & $0.052 * *$ & $0.064 * *$ & $0.016 * *$ & $0.024 * * *$ \\
\hline & $(0.026)$ & 0.026 & $(0.007)$ & $(0.007)$ \\
\hline F-test & 0.130 & 0.130 & 0.010 & 0.020 \\
\hline
\end{tabular}

Notes: Linear probability estimates control for in-district status and high subsidy receipt and their interaction with gender, age, race, gender, race - gender interactions, place of birth, disability status, marital status, poverty level, migration status, weeks worked in the previous year, and in columns (2) and (4) closest CCTD. Standard errors are clustered at the census tract level. 
Table 8b

Estimates of the Effect of High Subsidy on Enrollment by Gender: 2000 Census

\begin{tabular}{|c|c|c|c|c|}
\hline \multirow{3}{*}{ Gender } & \multicolumn{4}{|c|}{ (I) Enrollment in Any College } \\
\hline & \multicolumn{2}{|c|}{ Aged $18-24$} & \multicolumn{2}{|c|}{ Aged 18 and Older } \\
\hline & (1) & $(2)$ & (3) & (4) \\
\hline \multirow[t]{2}{*}{ Female } & $0.050^{* * *}$ & $0.070^{* * *}$ & $0.013^{* * *}$ & $0.018^{* * *}$ \\
\hline & $(0.015)$ & $(0.015)$ & $(0.003)$ & $(0.003)$ \\
\hline \multirow[t]{2}{*}{ Male } & $0.048 * * *$ & $0.068 * * *$ & $0.015 * * *$ & $0.020 * * *$ \\
\hline & $(0.015)$ & $(0.015)$ & $(0.004)$ & $(0.003)$ \\
\hline \multirow[t]{2}{*}{ F-test } & 0.120 & 0.130 & 1.310 & 1.220 \\
\hline & \multicolumn{4}{|c|}{ (II) Enrollment in a Public College } \\
\hline \multirow[t]{2}{*}{ Gender } & Aged $18-24$ & & d 18 and Olde & \\
\hline & (1) & $(2)$ & (3) & (4) \\
\hline \multirow[t]{2}{*}{ Female } & $0.054^{* * *}$ & $0.074^{* * *}$ & $0.013^{* * *}$ & $0.018^{* * *}$ \\
\hline & $(0.016)$ & $(0.016)$ & $(0.004)$ & $(0.004)$ \\
\hline \multirow[t]{2}{*}{ Male } & $0.053 * * *$ & $0.072 * * *$ & $0.016 * * *$ & $0.021 * * *$ \\
\hline & $(0.016)$ & $(0.016)$ & $(0.004)$ & $(0.004)$ \\
\hline F-test & 0.060 & 0.070 & $3.840 * *$ & $3.680 *$ \\
\hline
\end{tabular}

Notes: Linear probability estimates control for in-district status and high subsidy receipt and their interaction with gender, age, race, gender, race - gender interactions, place of birth, disability status, marital status, poverty level, migration status, weeks worked in the previous year, and in columns ( 2 ) and (4) closest CCTD. Standard errors are clustered at the census tract level. 
Table 8c

Estimates of the Effect of High Subsidy on Enrollment by Gender: 2004-2011 ACS

\begin{tabular}{|c|c|c|c|c|}
\hline \multirow{3}{*}{ Gender } & \multicolumn{4}{|c|}{ (I) Enrollment in Any College } \\
\hline & \multicolumn{2}{|c|}{ Aged $18-24$} & \multicolumn{2}{|c|}{ Aged 18 and Older } \\
\hline & (1) & $(2)$ & (3) & (4) \\
\hline \multirow[t]{2}{*}{ Female } & 0.012 & $0.027^{* * *}$ & $0.005^{* *}$ & $0.010 * * *$ \\
\hline & $(0.009)$ & $(0.009)$ & $(0.002)$ & $(0.002)$ \\
\hline \multirow[t]{2}{*}{ Male } & $0.016 *$ & $0.031 * * *$ & $0.006 * * *$ & $0.011^{* * *}$ \\
\hline & (0.009) & $(0.009)$ & $(0.002)$ & $(0.002)$ \\
\hline \multirow[t]{2}{*}{ F-test } & 0.260 & 0.290 & 0.260 & 0.290 \\
\hline & \multicolumn{4}{|c|}{ (II) Enrollment in a Public College } \\
\hline \multirow[t]{2}{*}{ Gender } & Aged $18-24$ & & d 18 and Olde & \\
\hline & $(1)$ & $(2)$ & (3) & (4) \\
\hline \multirow[t]{2}{*}{ Female } & $0.027^{* * *}$ & $0.041^{* * *}$ & $0.007^{* * *}$ & $0.012^{* * *}$ \\
\hline & $(0.009)$ & (0.009) & $(0.002)$ & $(0.002)$ \\
\hline \multirow[t]{2}{*}{ Male } & $0.029 * * *$ & $0.043 * * *$ & $0.009 * * *$ & $0.013 * * *$ \\
\hline & $(0.009)$ & $(0.009)$ & $(0.002)$ & $(0.002)$ \\
\hline F-test & 0.090 & 0.100 & 0.550 & 0.590 \\
\hline
\end{tabular}

Notes: Linear probability estimates control for in-district status and high subsidy receipt and their interaction with gender, age, race, gender, race - gender interactions, place of birth, disability status, marital status, poverty level, migration status, weeks worked in the previous year, and in columns (2) and (4) closest CCTD. Standard errors are clustered at the census tract level. 
Table 9a

Estimates of the Effect of High Subsidy on Enrollment by Poverty Level: 1990 Census

\begin{tabular}{|c|c|c|c|c|c|}
\hline \multirow{3}{*}{$\begin{array}{l}\text { \% of } \\
\text { Poverty } \\
\text { Level }\end{array}$} & \multicolumn{5}{|c|}{ (I) Enrollment in Any College } \\
\hline & \multicolumn{2}{|c|}{ Aged $18-24$} & \multicolumn{3}{|c|}{ Aged 18 and Older } \\
\hline & (1) & (2) & (3) & (4) & \\
\hline \multirow[t]{2}{*}{$<100 \%$} & 0.018 & 0.030 & 0.024 & 0.032 & * \\
\hline & $(0.034)$ & $(0.034)$ & $(0.017)$ & $(0.018)$ & \\
\hline \multirow[t]{2}{*}{$100 \%-199 \%$} & $0.049 * *$ & $0.060 * * *$ & $0.021 * * *$ & 0.028 & $* * *$ \\
\hline & $(0.020)$ & $(0.020)$ & $(0.006)$ & $(0.006)$ & \\
\hline \multirow[t]{2}{*}{$200 \%-299 \%$} & $0.035 *$ & $0.047 * *$ & $0.010 *$ & 0.017 & $* * *$ \\
\hline & $(0.020)$ & $(0.020)$ & $(0.005)$ & $(0.006)$ & \\
\hline \multirow[t]{2}{*}{$300 \%-399 \%$} & $0.049 * *$ & $0.062 * * *$ & $0.014 * * *$ & 0.021 & $* * *$ \\
\hline & $(0.020)$ & $(0.021)$ & $(0.005)$ & $(0.006)$ & \\
\hline \multirow[t]{2}{*}{$400 \%-499 \%$} & 0.019 & 0.031 & 0.008 & 0.015 & $* * *$ \\
\hline & $(0.022)$ & $(0.023)$ & $(0.006)$ & $(0.006)$ & \\
\hline \multirow[t]{2}{*}{$500 \%+$} & 0.030 & $0.043 * *$ & 0.008 & 0.015 & $* * *$ \\
\hline & $(0.021)$ & $(0.022)$ & $(0.005)$ & $(0.006)$ & \\
\hline F-test & 1.26 & 1.21 & $2.76^{* *}$ & 2.71 & $* *$ \\
\hline$\%$ of & \multicolumn{5}{|c|}{ (II) Enrollment in a Public College } \\
\hline \multirow{2}{*}{$\begin{array}{l}\text { Poverty } \\
\text { Level }\end{array}$} & \multicolumn{2}{|c|}{ Aged 18 - 24} & \multicolumn{3}{|c|}{ Aged 18 and Older } \\
\hline & (1) & $(2)$ & (3) & (4) & \\
\hline \multirow[t]{2}{*}{$<100 \%$} & $0.101^{* *}$ & $0.114^{* *}$ & $0.056^{* *}$ & 0.063 & $* * *$ \\
\hline & $(0.049)$ & $(0.049)$ & $(0.022)$ & $(0.022)$ & \\
\hline \multirow[t]{2}{*}{$100 \%-199 \%$} & $0.043 *$ & $0.055 * *$ & $0.018 * * *$ & 0.025 & $* * *$ \\
\hline & $(0.023)$ & $(0.024)$ & $(0.006)$ & $(0.007)$ & \\
\hline \multirow[t]{2}{*}{$200 \%-299 \%$} & 0.027 & $0.040 *$ & 0.008 & 0.015 & $* *$ \\
\hline & $(0.023)$ & $(0.024)$ & $(0.006)$ & $(0.006)$ & \\
\hline \multirow[t]{2}{*}{$300 \%-399 \%$} & $0.043 *$ & $0.056 * *$ & $0.012 *$ & 0.019 & $* * *$ \\
\hline & $(0.024)$ & $(0.025)$ & $(0.006)$ & $(0.007)$ & \\
\hline \multirow[t]{2}{*}{$400 \%-499 \%$} & 0.018 & 0.031 & 0.005 & 0.012 & $*$ \\
\hline & $(0.026)$ & $(0.027)$ & $(0.006)$ & $(0.007)$ & \\
\hline \multirow[t]{2}{*}{$500 \%+$} & 0.028 & 0.041 & 0.005 & 0.013 & $* *$ \\
\hline & $(0.025)$ & $(0.026)$ & $(0.006)$ & $(0.006)$ & \\
\hline F-test & 1.22 & 1.17 & $3.59 * * *$ & 3.55 & $* * *$ \\
\hline
\end{tabular}

Notes: Linear probability estimates control for in-district status and high subsidy receipt and their interaction with poverty level, age, race, gender, race - gender interactions, place of birth, disability status, marital status, poverty level, migration status, weeks worked in the previous year, and in columns (2) and (4) closest CCTD. Standard errors are clustered at the census tract level. 
Table 9b

Estimates of the Effect of High Subsidy on Enrollment by Poverty Level: 2000 Census

\begin{tabular}{|c|c|c|c|c|c|c|c|c|}
\hline \multirow{3}{*}{$\begin{array}{l}\% \text { of } \\
\text { Poverty } \\
\text { Level }\end{array}$} & \multicolumn{8}{|c|}{ (I) Enrollment in Any College } \\
\hline & \multicolumn{4}{|c|}{ Aged $18-24$} & \multicolumn{4}{|c|}{ Aged 18 and Older } \\
\hline & $(1)$ & & $(2)$ & & (3) & & $(4)$ & \\
\hline \multirow[t]{2}{*}{$<100 \%$} & $0.084^{*}$ & $* * *$ & 0.105 & $* * *$ & $0.024^{*}$ & $* *$ & 0.029 & $* * *$ \\
\hline & $(0.024)$ & & $(0.024)$ & & $(0.010)$ & & (0.010) & \\
\hline \multirow[t]{2}{*}{$100 \%-199 \%$} & $0.057 *$ & $* * *$ & 0.077 & $* * *$ & $0.015 *$ & $* * *$ & 0.020 & $* * *$ \\
\hline & $(0.015)$ & & $(0.015)$ & & $(0.004)$ & & (0.004) & \\
\hline \multirow[t]{2}{*}{$200 \%-299 \%$} & $0.039 *$ & $* * *$ & 0.059 & $* * *$ & $0.011 *$ & $* * *$ & 0.017 & $* * *$ \\
\hline & $(0.015)$ & & $(0.014)$ & & $(0.003)$ & & (0.003) & \\
\hline \multirow[t]{2}{*}{$300 \%-399 \%$} & $0.039 *$ & $* *$ & 0.058 & $* * *$ & $0.013 *$ & $* * *$ & 0.018 & $* * *$ \\
\hline & $(0.016)$ & & $(0.016)$ & & $(0.004)$ & & $(0.003)$ & \\
\hline \multirow[t]{2}{*}{$400 \%-499 \%$} & $0.032 *$ & $* *$ & 0.050 & $* * *$ & $0.012 *$ & $* * *$ & 0.017 & $* * *$ \\
\hline & $(0.017)$ & & $(0.017)$ & & $(0.004)$ & & (0.004) & \\
\hline \multirow[t]{2}{*}{$500 \%+$} & 0.021 & & 0.039 & $* *$ & $0.010 *$ & $* * *$ & 0.015 & $* * *$ \\
\hline & $(0.016)$ & & $(0.016)$ & & $(0.003)$ & & $(0.003)$ & \\
\hline F-test & $2.30^{*}$ & $* *$ & 2.62 & $* *$ & 0.91 & & 1.06 & \\
\hline$\%$ of & \multicolumn{8}{|c|}{ (II) Enrollment in a Public College } \\
\hline Poverty & \multicolumn{4}{|c|}{ Aged 18 - 24} & \multicolumn{4}{|c|}{ Aged 18 and Older } \\
\hline Level & $(1)$ & & $(2)$ & & (3) & & (4) & \\
\hline \multirow[t]{2}{*}{$<100 \%$} & $0.121^{*}$ & $* * *$ & 0.142 & $* * *$ & $0.036^{*}$ & $* * *$ & 0.041 & $* * *$ \\
\hline & $(0.026)$ & & $(0.026)$ & & $(0.010)$ & & (0.010) & \\
\hline \multirow[t]{2}{*}{$100 \%-199 \%$} & $0.060 *$ & $* * *$ & 0.080 & $* * *$ & $0.015 *$ & $* * *$ & 0.020 & $* * *$ \\
\hline & $(0.016)$ & & $(0.016)$ & & $(0.004)$ & & (0.004) & \\
\hline \multirow[t]{2}{*}{ 200\%-299\% } & $0.039 *$ & $* *$ & 0.058 & $* * *$ & $0.012 *$ & $* * *$ & 0.017 & $* * *$ \\
\hline & $(0.016)$ & & $(0.015)$ & & $(0.003)$ & & (0.003) & \\
\hline \multirow[t]{2}{*}{ 300\%-399\% } & $0.033 *$ & $*$ & 0.052 & $* * *$ & 0.012 * & $* * *$ & 0.017 & $* * *$ \\
\hline & $(0.017)$ & & $(0.016)$ & & $(0.004)$ & & (0.003) & \\
\hline \multirow[t]{2}{*}{ 400\%-499\% } & 0.019 & & 0.036 & $* *$ & $0.010 *$ & $* * *$ & 0.015 & $* * *$ \\
\hline & $(0.018)$ & & $(0.018)$ & & $(0.004)$ & & (0.004) & \\
\hline \multirow[t]{2}{*}{$500 \%+$} & 0.009 & & 0.026 & & $0.008 *$ & $* *$ & 0.013 & $* * *$ \\
\hline & $(0.017)$ & & $(0.016)$ & & $(0.003)$ & & $(0.003)$ & \\
\hline F-test & $6.00^{*}$ & $* * *$ & 6.53 & $* * *$ & $2.34^{*}$ & $* *$ & 2.59 & $* *$ \\
\hline
\end{tabular}

Notes: Linear probability estimates control for in-district status and high subsidy receipt and their interaction with poverty level, age, race, gender, race - gender interactions, place of birth, disability status, marital status, poverty level, migration status, weeks worked in the previous year, and in columns (2) and (4) closest CCTD. Standard errors are clustered at the census tract level. 
Table 9c

Estimates of the Effect of High Subsidy on Enrollment by Poverty Level: 2004-2011 ACS

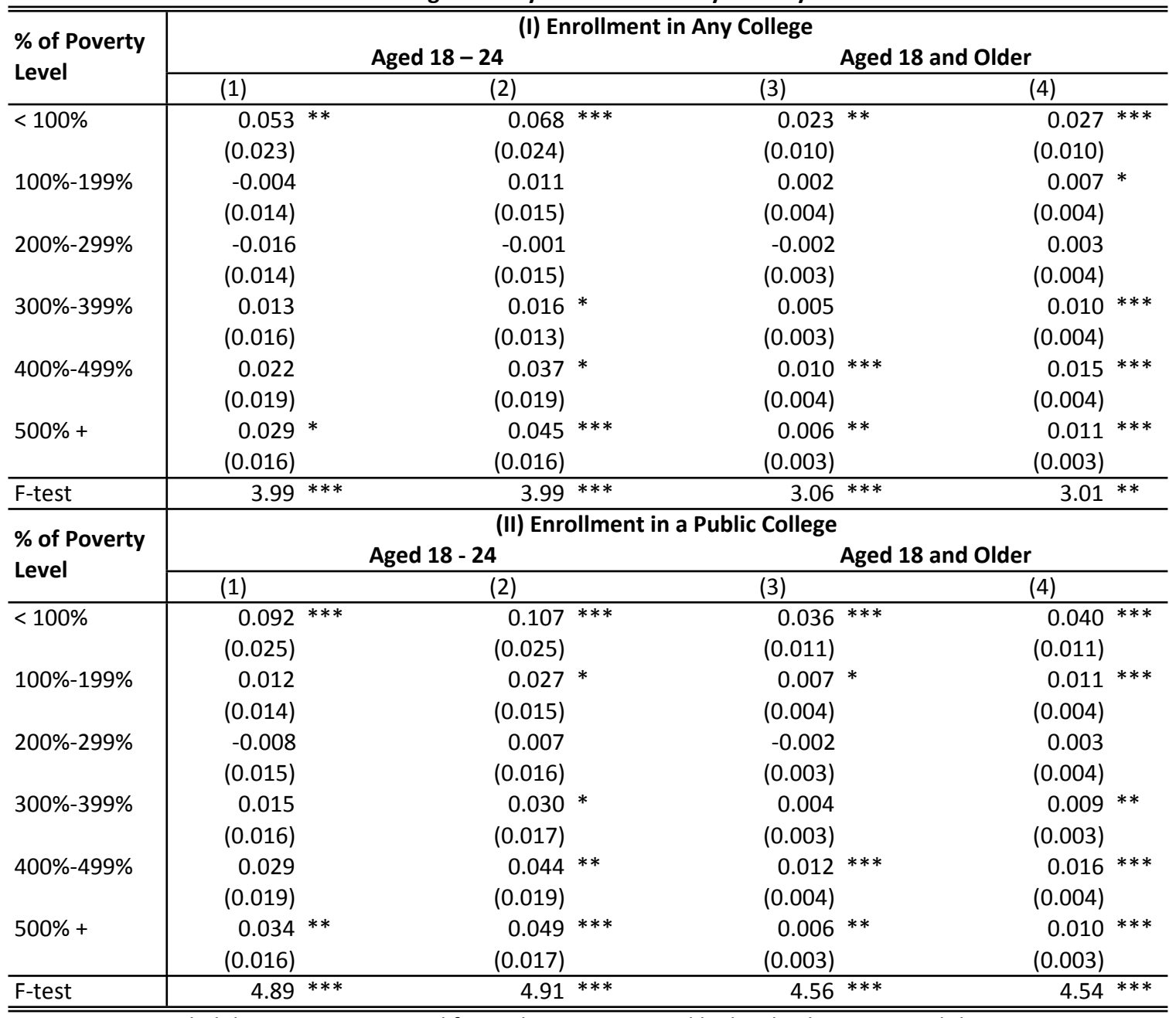

Notes: Linear probability estimates control for in-district status and high subsidy receipt and their interaction with poverty level, age, race, gender, race - gender interactions, place of birth, disability status, marital status, poverty level, migration status, weeks worked in the previous year, and in columns (2) and (4) closest CCTD. Standard errors are clustered at the census tract level. 